\title{
Oceanic Pb-Isotopic Sources of Proterozoic and Paleozoic Volcanogenic Massive Sulfide Deposits on Prince of Wales Island and Vicinity, Southeastern Alaska
}

\author{
By Robert A. Ayuso, Susan M. Karl, John F. Slack, Peter J. Haeussler, Peter E. Bittenbender, ${ }^{1}$ \\ Gregory A. Wandless, and Anna S. Colvin
}

\section{Abstract}

Volcanogenic massive sulfide (VMS) deposits on Prince of Wales Island and vicinity in southeastern Alaska are associated with Late Proterozoic through Cambrian volcanosedimentary rocks of the Wales Group and with Ordovician through Early Silurian felsic volcanic rocks of the Moira Sound unit (new informal name). The massive sulfide deposits in the Wales Group include the Big Harbor, Copper City, Corbin, Keete Inlet, Khayyam, Ruby Tuesday, and Stumble-On deposits, and those in the Moira Sound unit include the Barrier Islands, Moira Copper, Niblack, and Nichols Bay deposits.

$\mathrm{Pb}$-isotopic signatures were determined on sulfide minerals (galena, pyrite, chalcopyrite, pyrrhotite, and sphalerite) to constrain metal sources of the massive sulfides and for comparison with data for other deposits in the region. Except for the Ruby Tuesday deposit, galena is relatively rare in most of these deposits. Pb-isotopic signatures distinguish the mainly $\mathrm{Cu}+\mathrm{Zn} \pm \mathrm{Ag} \pm \mathrm{Au}$ massive sulfide deposits in the Wales Group from the $\mathrm{Zn}+\mathrm{Cu} \pm \mathrm{Ag} \pm \mathrm{Au}$ massive sulfide deposits in the Moira Sound unit. Among the older group of deposits, the Khayyam deposit has the widest variation in $\mathrm{Pb}$-isotopic ratios $\left({ }^{206} \mathrm{~Pb} /{ }^{204} \mathrm{~Pb}=17.169-18.021,{ }^{207} \mathrm{~Pb} /{ }^{204} \mathrm{~Pb}=15.341-15.499\right.$, $\left.{ }^{208} \mathrm{~Pb} /{ }^{204} \mathrm{~Pb}=36.546-37.817\right)$; data for the other massive sulfide deposits in the Wales Group overlap the isotopic variations in the Khayyam deposit. $\mathrm{Pb}$-isotopic ratios for both groups of deposits are lower than those on the average crustal $\mathrm{Pb}$ evolution curve $(\mu=9.74)$, attesting to a large mantle influence in the $\mathrm{Pb}$ source. All the deposits show no evidence for $\mathrm{Pb}$ evolution primarily in the upper or lower continental crust. Samples from the younger group of deposits have scattered $\mathrm{Pb}$-isotopic compositions and plot as a broad band on uranogenic and thorogenic $\mathrm{Pb}$ diagrams. Data for these deposits overlap the trend for massive sulfide deposits in the Wales Group but extend to significantly more radiogenic $\mathrm{Pb}$-isotopic values. $\mathrm{Pb}$-isotopic ratios of samples from the massive sulfide deposits in the Moira Sound unit plot on a different trend

${ }^{1}$ U.S. Bureau of Land Management. $\left({ }^{206} \mathrm{~Pb} /{ }^{204} \mathrm{~Pb}=17.375-19.418,{ }^{207} \mathrm{~Pb} /{ }^{204} \mathrm{~Pb}=15.361-15.519\right.$, $\left.{ }^{208} \mathrm{~Pb} /{ }^{204} \mathrm{~Pb}=36.856-37.241\right)$ from the steep slope defined by the massive sulfide deposits in the Wales Group. In comparison, the $\mathrm{Pb}$-isotopic ratios of Devonian polymetallic $(\mathrm{Pb}-\mathrm{Zn}-\mathrm{Au}-\mathrm{Ag})$ quartz-sulfide veins vary widely $\left({ }^{206} \mathrm{~Pb} /{ }^{204} \mathrm{~Pb}=18.339-18.946,{ }^{207} \mathrm{~Pb} /{ }^{204} \mathrm{~Pb}=15.447-15.561\right.$, $\left.{ }^{208} \mathrm{~Pb} /{ }^{204} \mathrm{~Pb}=37.358-38.354\right)$, straddling the slope defined by the massive sulfide deposits in the Moira Sound unit. The general decrease in ${ }^{207} \mathrm{~Pb} /{ }^{204} \mathrm{~Pb}$ ratio in these deposits, relative to the average crustal $\mathrm{Pb}$-evolution curve, suggests that the most likely lead sources were those associated with oceanic volcanic rocks. The massive sulfide deposits in the Wales Group may have resided within an intraoceanic tectonic setting where the mantle was the predominant contributor of metals. Some contribution from reworked arc material or recycled older, hydrothermally altered oceanic crust (including pelagic sediment) is also possible. Lead sources of the massive sulfide deposits in the Moira Sound unit also included an older source region, possibly a Late Proterozoic or Cambrian volcanosedimentary sequence and the massive sulfide deposits in the Wales Group. Preliminary regional comparison of the $\mathrm{Pb}$-isotopic data indicates that the Greens Creek (Admiralty Island, Alaska) and Windy Craggy (northern British Columbia) deposits probably did not share a common lead source with the VMS deposits on Prince of Wales Island. Other sulfide occurrences on Admiralty Island are also more radiogenic than those on Prince of Wales Island. Large differences in ${ }^{207} \mathrm{~Pb} /{ }^{204} \mathrm{~Pb}$ ratio suggest that the lead in the VMS deposits in different parts of the Alexander terrane evolved from sources with heterogeneous $\mathrm{U} / \mathrm{Pb}$ ratios, resulting from mixing of mantle and crustal components.

\section{Introduction}

We have investigated the $\mathrm{Pb}$-isotopic evolution of the volcanogenic massive sulfide (VMS) deposits on Prince of Wales Island and adjacent areas in southeastern Alaska to better understand the regional metallogeny of the Alaskan Cordillera 
(fig. 1). These deposits include an older group in Late Proterozoic through Cambrian volcanosedimentary rocks of the Wales Group and a younger group in Ordovician through Early Silurian felsic volcanic rocks of the Moira Sound unit (new informal name) (fig. 1; S.M. Karl and others, unpub. data, 2006). The $\mathrm{Pb}$-isotopic data reported here provide insights into the mineralizing processes and postmineralization disturbances. Additionally, the Pb-isotopic compositions help identify possible sources that may have contributed metals to the deposits (for example, Farmer and DePaolo, 1997; Richards and Noble, 1998) and provide key fingerprints for regional metallogenic comparisons.

\section{Regional Setting}

Southeastern Alaska and the Canadian Cordillera consist of continental and oceanic terranes that were accreted to the North American craton from Late Cambrian through Middle Cretaceous time (Berg and others, 1972), including, in this part of the Cordillera, the Alexander-Wrangellia-Peninsular, Chugach, Stikinia, Taku, and Yukon-Tanana terranes (for example, Gehrels and Saleeby, 1987; Monger and Berg, 1987; Samson and others, 1991). Southeastern Alaska and Canada, particularly the Alexander-Wrangellia-Peninsular composite terrane, includes numerous base-metal deposits and is part of an extensive regional metallogenic belt, within which is the largest VMS deposit in southeastern Alaska (Greens Creek), formed in the Triassic, as well as many other VMS deposits that formed as early as the Late Proterozoic (for example, Goldfarb, 1997; Newberry and Brew, 1997; Newberry and others, 1997).

The comprehensive sequence of Late Proterozoic through Jurassic rocks that is preserved in the Alexander terrane uniquely underscores the importance of this terrane to the evolution of the west flank of North America (Gehrels and others, 1996). Transportation and juxtaposition of the Alexander terrane adjacent to unrelated rock sequences have long been known, but the tectonic evolution of the terrane remains controversial. Although relatively small displacements have been proposed (Jones and others, 1972; Churkin and Eberlein, 1977), detailed geologic studies invoke large displacements, with an origin unrelated to the Cordilleran margin. The Alexander terrane may originally have been situated in the Uralian seaway between the Siberian paleocontinent and the eastern margin of the Baltic shield (for example, Blodgett and others, 2002) or near a Gondwanan margin (for example, the Transantarctic Mountains; Gehrels and Saleeby, 1987; Soja and Antoshkina, 1997). The terrane was displaced during the Jurassic through Early Cretaceous along the western margin of North America (Monger and others, 1982; Gehrels and others, 1996).

\section{Geology}

The VMS deposits on Prince of Wales and adjacent islands, which are assigned to the Alexander terrane, are hosted by two lithotectonic sequences of mafic and felsic metavolcanic rocks and siliciclastic and calcareous metasedimentary rocks (Karl and others, 1999a, b; S.M. Karl and others, unpub. data, 2006). The mineral deposits in southeastern Alaska, which may be the oldest VMS deposits (Late Proterozoic through Cambrian) in this part of the Cordillera, include younger (Ordovician through Early Silurian) massive sulfide deposits, as well as polymetallic quartz-sulfide veins of varying age (Ordovician through Devonian on Prince of Wales Island and Cretaceous on Gravina Island).

The Late Proterozoic through Cambrian metamorphosed VMS deposits, which are hosted in mafic and felsic schist of the Wales Group (S.M. Karl and others, unpub. data, 2006), include the Big Harbor, Copper City, Corbin, Keete Inlet, Khayyam, Nutkwa, Ruby Tuesday, and Stumble-On deposits (fig. 1), all of which have been analyzed for $\mathrm{Pb}$ isotopes except the Nutkwa deposit (no samples available). The host rocks and massive sulfide deposits in the Wales Group were affected by two ductiledeformational events and by varying degrees of metamorphism, from greenschist to amphibolite grade (see Haeussler and others, this volume). The earliest deformational fabric in the rocks of the Wales Group is cut by plutonic rocks with a U-Pb zircon age of 554 \pm 4 m.y. (Gehrels and Saleeby, 1987; Gehrels, 1990). The principal metals in most of the massive sulfide deposits in the Wales Group are silver and base metals except in the Ruby Tuesday deposit, which is relatively $\mathrm{Pb}$ enriched (Karl and others, 2003; see Slack and others, this volume). These deposits are hosted by dominantly tholeiitic mafic flows, breccias, and volcaniclastic rocks, with subordinate layered felsic extrusive and volcaniclastic rocks (Gehrels and Saleeby, 1987). Associated protoliths include algal-laminated, silty, massive limestone, minor conglomerate, sandstone, and mudstone. Mafic to felsic dikes and sills of uncertain age are also present. The host rocks have a metamorphic fabric that predates intrusion by intermediate-composition plutons with concordant zircon $\mathrm{U}-\mathrm{Pb}$ ages ranging from 520 to 560 m.y. (Gehrels, 1990; S.M. Karl and others, unpub. data, 2006). A regional metamorphic event that reached middle amphibolite grade affected the Wales Group at 484 m.y. (K-Ar metamorphic age on hornblende and on material from a whole-rock sample; Herreid and others, 1978; Eberlein and others, 1983; Gehrels and Saleeby, 1987; Zumsteg and others, 2004).

\section{Precambrian Deposits}

In the Wales Group, sulfide minerals typically include coarse-grained pyrite with interstitial chalcopyrite and sphalerite (fig. 2); pyrrhotite is common in some deposits (for example, the Khayyam deposit, fig. 1; see Maas and others, 1995). Galena is rare except at the Ruby Tuesday (Fish Show) deposit (and the Polymetal prospect), but it also occurs in minor amounts at the Big Harbor, Copper City, and Nutkwa deposits. The coarse grain size ( $>1-\mathrm{cm}$ diameter) of the deposits reflects extensive metamorphic recrystallization, as does the relatively depleted $\mathrm{Hg}$ and $\mathrm{Te}$ contents in some sulfide samples (for example, from the Khayyam deposit; see Slack and others, this volume). The abundance of pyrrhotite is consistent with 


\section{EXPLANATION}

\section{Intrusive rocks}

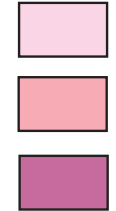

Mesozoic plutons

Paleozoic plutons

Upper Proterozoic plutons

\section{Stratified rocks}

$\square$ Silurian and younger strata, undivided
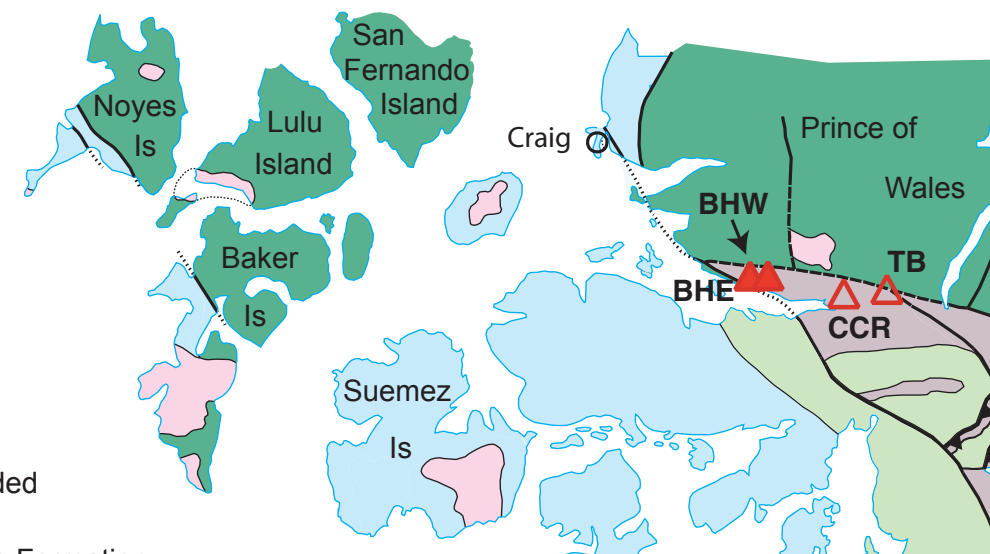

Silurian through Ordovician Descon Formation

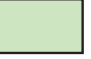

Lower Silurian through Ordovician Moira Sound unit and correlatives

Cambrian through Upper Proterozoic Wales Group

\section{Volcanogenic massive sulfides}

Moira Group (and correlative) deposit

Moira Group (and correlative) occurrence

- Wales Group deposit

$\triangle$ Wales Group occurrence

\section{Stratabound barite}

Wales Group deposit

Faults

- High-angle fault

ـ Thrust fault

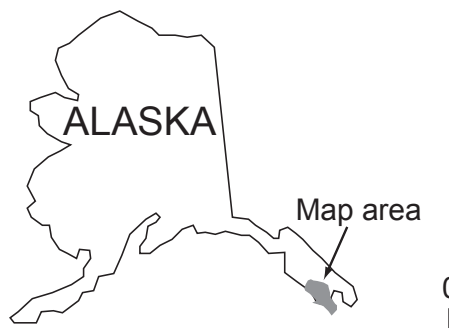

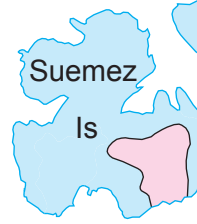

0
10 $20 \mathrm{~K}$ $55^{\circ} 30^{\prime}$

$132^{\circ} 00^{\prime}$

Figure 1. Simplified geologic map of southern Prince of Wales Island and vicinity, showing locations of volcanogenic massive sulfide deposits and occurrences (from Slack and others, this volume). Geology from S.M. Karl and others (unpub. data, 2006). Deposits and occurrences: BHE, Big Harbor East; BHW, Big Harbor West; BI, Barrier Islands; CB, Corbin; CC, Copper City; CCR, Cable Creek roadcut; DB, Deer Bay; DH, Datzkoo Harbor; DM, Dama; EL, Eek Lake; HZ, Hozer; KI, Keete Inlet; KIN, Keete Inlet North; KY, Khayyam; LO, Lookout Mountain; LP, Lime Point (barite); LS, Lindsey/88; MC, Moira Copper; NB, Nichols Bay; NKM, Nutkwa Main; NKN, Nutkwa North; NL, Niblack; RL, Rock Lake; RTF, Ruby Tuesday (Fish Show; includes the Chomly deposit); RTP, Ruby Tuesday (Polymetal prospect); SC, Security Cove; S0, Stumble-On; TB, Trocadero Bay. Numbered suffixes for Barrier Islands (BI-1 through BI-6) and Nichols Bay (NB-7 through NB-10) deposits and occurrences correspond to those of Gehrels and others (1983a). 
high-grade metamorphism of the sulfides. The massive sulfide deposits in the Wales Group are base-metal rich and have higher $\mathrm{Cu} / \mathrm{Zn}$ ratios than do the massive sulfide deposits in the younger Moira Sound unit (see Slack and others, this volume). S-isotopic studies suggest that the lower $\delta^{34} \mathrm{~S}$ of sulfide samples from the Moira Sound unit, relative to those from the Wales Group, may reflect isotopically lighter seawater sulfate during the Ordovician than during the Late Proterozoic through Cambrian (see Slack and others, this volume).

\section{Paleozoic Deposits}

A younger group of massive sulfide deposits is hosted in Ordovician through Early Silurian felsic volcanic rocks of the Moira Sound unit (see Maas and others, 1995, and references therein), which rests unconformably on the Wales Group (S.M. Karl and others, unpub. data, 2006). The Ordovician sulfide deposits occur on the Barrier Islands, Nichols Bay, near Niblack Anchorage (Dama and Lookout Mountain prospects), and in Moira Sound (fig. 1). Principal metals are gold, silver, and base metals (S.M. Karl and others, unpub. data, 2006). The deposits generally are proportionately richer in Ag relative to base metals and Au than are the massive sulfide deposits in the Wales Group (see Slack and others, this volume). Host rocks of the massive sulfide deposits in the Moira Sound unit are dominantly intermediate to felsic in composition and include volcaniclastic protoliths (S.M. Karl and others, unpub. data, 2006). Felsic pyroclastic rocks and silicic rhyolite intrusions are intercalated with the mafic volcanic rocks, in addition to volcanic wacke and mudstone turbidites, black carbonaceous limestone, bedded limestone, chert, and argillite containing Early through Late Ordovician graptolites and conodonts (S.M. Karl and others, unpub. data, 2006).

Relative to the Wales Group, rocks of the Moira Sound unit and associated massive sulfide deposits are less deformed and have a lower metamorphic grade (greenschist facies). Two deformation events (ductile in the Devonian and brittle in the Cretaceous) and one folding event have affected the Moira Sound unit (see Haeussler and others, this volume). Sedimentary rocks retained primary turbidite textures, and igneous rocks retained primary porphyritic textures. Widespread intermediate-composition plutons yield zircon $\mathrm{U}-\mathrm{Pb}$ ages of 427-438 and 465-480 m.y. (Gehrels, 1992; R. Friedman, written commun., 2005; S.M. Karl and others, unpub. data, 2006). Dacite yields a U-Pb zircon age of 475 m.y., and basalts contain amphiboles with an Ar-Ar age of 484 m.y. (J. Wooden, in Karl and others, 2003). Volcanic rocks of the Moira Sound unit have stronger calc-alkaline affinities than those of the Wales Group (S.M. Karl and others, unpub. data, 2006). Conglomerates of the Moira Sound unit contain clasts of schist and marble derived from the Wales Group, as well as two populations of detrital zircons based on $\mathrm{U}-\mathrm{Pb}$ ages (larger zircons, 480 m.y.; smaller zircons, 540-600 m.y.; J. Wooden, in S.M. Karl and others, unpub. data, 2006). Pyroclastic rocks contain clasts of chlorite schist and rounded, probably detrital zircons with an age of 595 m.y. (Gehrels and others, 1996; and G.E. Gehrels written comm., 2003). Metamorphic rocks of the Moira Sound unit contain low-greenschist-facies minerals, including chlorite and epidote, and have a pervasive fabric. The date of this metamorphism is inferred to correspond to the $392-410-\mathrm{m} . \mathrm{y} .{ }^{40} \mathrm{Ar} /{ }^{39} \mathrm{Ar}$ ages of white mica and biotite that locally replace amphibole in rocks of the Wales Group. White mica from the Moira Sound unit also yields a Devonian age (see Haeussler and others, this volume).

In the Moira Sound unit, the massive sulfide deposits are dominantly composed of fine-grained pyrite, chalcopyrite, sphalerite, and, in some samples, sparse galena (Maas and others, 1995). Many of these deposits contain relict features indicative of sea-floor and sub-sea-floor hydrothermal processes (fig. 2), for example, in the Niblack area (Dama and Lookout Mountain prospects) and in the Barrier Islands (Karl and others, 2003; see Slack and others, this volume). Galena has been obtained from the Niblack and Barrier Islands deposits; pyrrhotite is rare. The massive sulfide deposits in the Moira Sound unit generally have a higher average Au+Ag content than do those in the Wales Group, and a higher average $\mathrm{Ag}$ content relative to $\mathrm{Cu}+\mathrm{Pb}+\mathrm{Zn}$ contents (see Slack and others, this volume).

\section{Polymetallic Quartz-Sulfide Veins}

A small group of polymetallic ( $\mathrm{Pb}-\mathrm{Zn}$-Au-Ag) quartzsulfide veins on Prince of Wales Island were also analyzed for $\mathrm{Pb}$ isotopes. Late Proterozoic through Cambrian schist and gneiss of the Wales Group host many of these quartz-sulfide veins (for example, at the Lady of the Lake, Moonshine, Lucky Boy, and Port Bazan deposits; see fig. 2). Quartz-sulfide veins are rare in post-Ordovician rocks on Prince of Wales and Dall Islands (Herreid and others, 1978). Two generations of quartz veins have been noted, for example, in association with the polymetallic quartz-sulfide veins at the Moonshine deposit (Herreid and others, 1978). The undeformed quartz veins cut through folded quartz veins and may reflect mineralization associated with regional Devonian ( $\leq 410 \mathrm{Ma}$; Karl and others, 2005; see Haeussler and others, this volume) crustal extension, but their exact age is unknown. In contrast to the massive sulfide deposits, the polymetallic quartz-sulfide veins are commonly galena rich (for example, at the Lucky Boy and Moonshine deposits). The veins also contain pyrite, chalcopyrite, sphalerite, and, in some places, sparse barite (Herreid and others, 1978; Maas and others, 1995). Dolomite-bearing quartz-sulfide veins are common in rocks of the Wales Group (for example, at the Moonshine deposit) but have never been observed in rocks of the Moira Sound unit (Herreid and others, 1978). At the Dew Drop deposit, a gold-bearing quartz fissure vein occurs in a fault cutting folded Ordovician metavolcanic and volcaniclastic greywacke turbidites of the Descon Formation (Churkin and Eberlein, 1977; S.M. Karl and others, unpub. data, 2006) that are part of an andesitic arc which does not rest on the Wales Group. In addition to galena, the fissure vein contains pyrite, chalcopyrite, and sphalerite. 

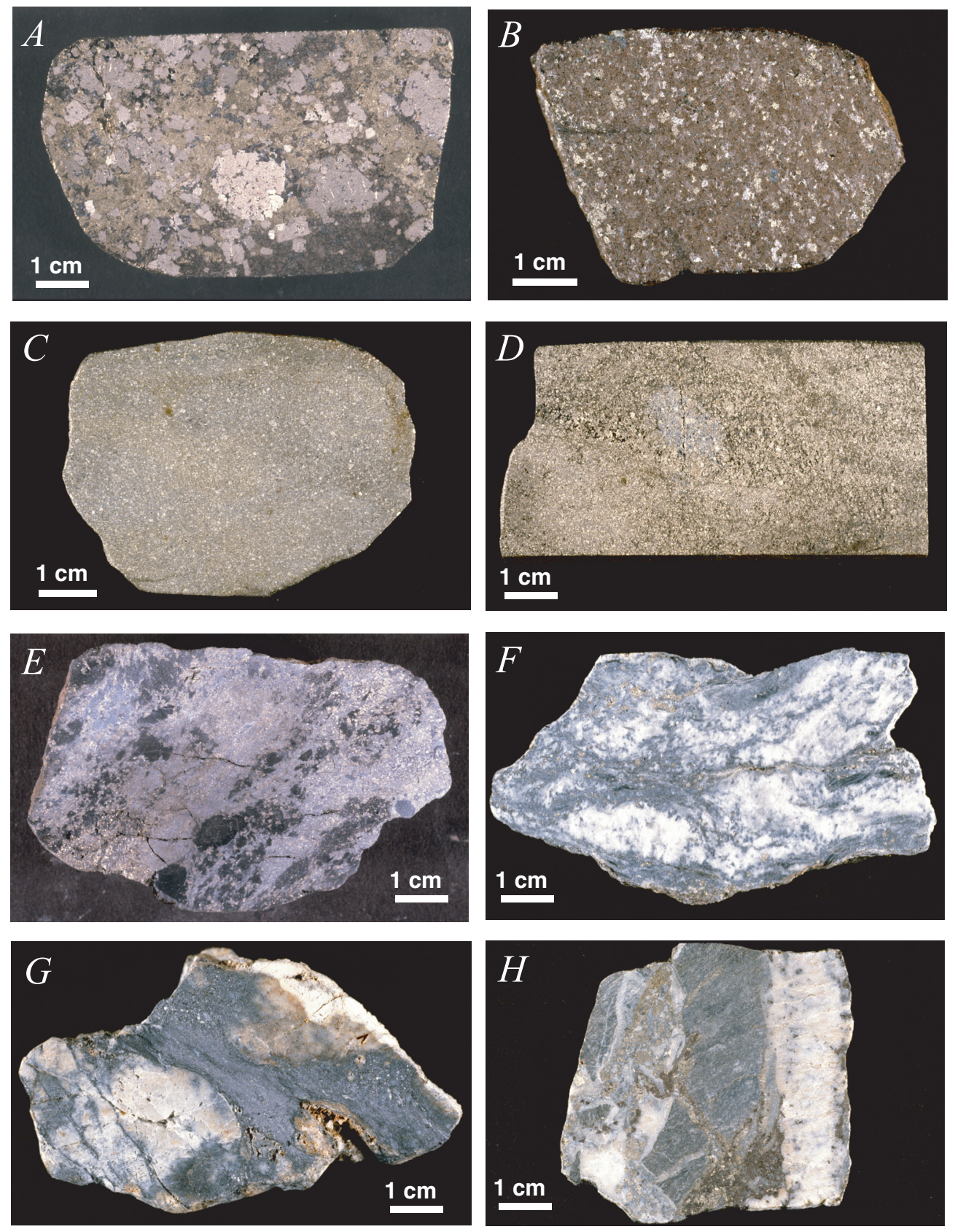

Figure 2. Representative sulfide-rich samples used in this study. $A$, Very coarse grained, porphyroblastic pyrite within a matrix of chalcopyrite, pyrrhotite (partially altered to marcasite), and minor sphalerite. Sample JS-00-36A from Stumble-On Mine dump. B, Coarse-grained disseminated pyrite (minor) within a matrix of coarse-grained sphalerite (abundant). Sample JS-00-36C from Stumble-On Mine dump. C, Pyritic massive sulfide with minor interstitial sphalerite and trace chalcopyrite. Sample JS-00-53A from Keete Inlet Mine dump. D, Pyritic massive sulfide and minor chalcopyrite. Sample L0-99/367 from the Lookout Mountain prospect. $E$, High-grade polymetallic massive sulfide with abundant sphalerite and galena including minor chalcopyrite, with relict volcanic clasts (dark). Sample RT-FS-MS from Ruby Tuesday (Fish Show) Mine dump. $F$, Deformed quartz-carbonate vein with minor pyrite, sphalerite, and galena. Sample JS-00-49B from Ruby Tuesday prospect area. G, Deformed quartz-galena vein with sparse sphalerite. Sample 84AGK052B from the Moonshine prospect. $H$, Undeformed quartzpyrite-sphalerite vein with minor galena, cutting silicified sedimentary wallrock (gray). Sample 83AGK106C from the Lucky Boy prospect. 


\section{Mesozoic Sulfide-Bearing Quartz Veins}

Adjacent to Prince of Wales Island, on Gravina Island, two galena-bearing quartz veins, at the Goldstream and Seal Cove deposits, were sampled (Maas and others, 1995). Overlying the Alexander terrane are host rocks of the sulfidebearing quartz veins at the Goldstream locality, which include Cretaceous(?) and Jurassic intermediate composition to mafic volcanic and volcaniclastic rocks of the Gravina Island Formation (for example, Berg and others, 1972; Gehrels and others, 1983a, b). At Seal Cove, the quartz veins contain galena, barite, and sphalerite and are hosted in shears by Triassic rhyolite, Silurian trondhjemite, and schist and gneiss that probably represent the Wales Group. Host rocks of the veins at Seal Cove are part of the Alexander terrane. The date of vein mineralization at Seal Cove may be Triassic (Maas and others, 1995), equivalent to the age of the Greens Creek polymetallic massive sulfide deposit (Taylor and others, 1999).

\section{Analytical Procedures}

Sulfide minerals in the samples used for petrographic and stable-isotope studies (see Slack and others, this volume) were handpicked under a binocular microscope for $\mathrm{Pb}$ isotopic analysis. $\mathrm{Pb}$-isotopic compositions were determined on sulfide separates from samples of the Late Proterozoic through Cambrian massive sulfide deposits in the Wales Group (Big Harbor, Copper City, Corbin, Keete Inlet, Khayyam, Ruby Tuesday, and Stumble-On), the Ordovician through Early Silurian massive sulfide deposits in the Moira Sound unit (Barrier Islands, Moira Copper, and Niblack) and the polymetallic quartz-sulfide veins of uncertain age on Prince of Wales Island and vicinity. A total of $39 \mathrm{~Pb}$-isotopic analyses were performed. One group of analyses used about $50 \mathrm{mg}$ of sulfide after dissolution of the sample in $\mathrm{HNO}_{3}-\mathrm{HCl}$ or in $\mathrm{HF}$. Another group of analyses used sulfides that were leached in $1 N \mathrm{HBr}-2.5 N \mathrm{HCl}$ and then dissolved in $\mathrm{HNO}_{3}-\mathrm{HCl}$ to survey the full spectrum of isotopic compositions associated with acid-soluble lead; data for both leachates and residues were reported. $\mathrm{Pb}$ isotopes were purified by standard procedures and measured in static mode with a multicollector, automated Finnigan model MAT-262 mass spectrometer at the U.S. Geological Survey laboratory in Reston, Va. Runs were carefully monitored during analysis (for example, stable run temperatures of $1,350 \pm 25^{\circ} \mathrm{C}$ ) to minimize the effects of mass fractionation. $\mathrm{Pb}$-isotopic ratios were measured to a precision of $\sim 0.1$ percent at $2 \sigma$ and corrected for mass fractionation by comparison with ratios measured on National Bureau of Standards reference SRM 981 ( $n=28)$. Total Pb blanks during the course of this study were less than $50 \mathrm{pg}$, insignificant relative to $\mathrm{Pb}$ abundances in the hydrothermal sulfide and carbonate minerals. The ISOPLOT program (Ludwig, 1991) was used to calculate ages according to the Pb-evolution model of Stacey and Kramers (1975).

\section{Results}

$\mathrm{Pb}$-isotopic compositions of acid-leached aliquots and residues of sulfide minerals (galena, pyrite, chalcopyrite, pyrrhotite, and sphalerite) are plotted in figures 3 through 5 and listed in tables 1 through 3. Most analyses were obtained on $\mathrm{Fe}$ sulfides. As a group, the sulfides from massive sulfide deposits in the Wales Group and Moira Sound unit and from polymetallic quartz-sulfide veins plot below the average crustal $\mathrm{Pb}$-evolution curve ( $\mu=9.74$; Stacey and Kramers, 1975) on uranogenic $\mathrm{Pb}$ diagrams (relatively lower ${ }^{207} \mathrm{~Pb} /{ }^{204} \mathrm{~Pb}$ ratios), and to the right of this curve on thorogenic $\mathrm{Pb}$ diagrams (figs. 3-5). The average crustal $\mathrm{Pb}$-evolution curve is equivalent to that for the major reservoir of recycled continental crust (Doe and Zartman, 1979). Relatively unradiogenic $\mathrm{Pb}$-isotopic ratios for the massive sulfide deposits attest to a mantle influence in the lead source of all these deposits. Most of the Pb-isotopic compositions of leachates are broadly similar (mostly slightly less radiogenic) than those of residues.

$\mathrm{Pb}$-isotopic data from the VMS deposits plot on Prince of Wales Island and vicinity plot as two isotopic groups, corresponding to the various ages and stratigraphic sequences in the Wales Group and Moira Sound unit. Sulfides from the massive sulfide deposits in the Wales Group generally have a distinctive range in compositions (table 1), plotting along a steep, broad band that intersects the average crustal $\mathrm{Pb}$ evolution curve of Stacey and Kramers (1975). Among the older group of deposits, the Khayyam deposit has the widest variation in $\mathrm{Pb}$-isotopic ratios $\left({ }^{206} \mathrm{~Pb} /{ }^{204} \mathrm{~Pb}=17.169-18.021\right.$, ${ }^{207} \mathrm{~Pb} /{ }^{204} \mathrm{~Pb}=15.341-15.499,{ }^{208} \mathrm{~Pb} /{ }^{204} \mathrm{~Pb}=36.546-37.817$; figs. $3 A$, $3 B$; table 1 ). Considering the Khayyam deposit as representative of this older group of deposits yields a curve intercept at about 270 m.y., significantly younger than the presumed Cambrian (or older) mineralization age (fig. $3 A$ ). $\mathrm{Pb}$-isotopic variations in the other massive sulfide deposits in the Wales Group overlap those in the Khayyam deposit. Another significant feature of the older group of deposits is that significant amounts of galena occur only in the Ruby Tuesday deposit. Although the Pb-isotopic signatures of this galena (from the Fish Show deposit in this study and from the Polymetal prospect in Kucinski, 1987) are comparable to those of the Fe sulfide minerals that characterize the other massive sulfide deposits, together with the data for the Keete Inlet deposit they are somewhat shifted toward radiogenic ${ }^{206} \mathrm{~Pb} /{ }^{204} \mathrm{~Pb}$ ratios that are more typical of the younger group of deposits (figs. 3-4). We note that despite the significant geologic contrast in host rocks between the Polymetal prospect, which is near the top of a thick unit of felsic volcaniclastic schist (Kucinski, 1987), and the Fish Show deposit, which is in graphitic argillite (Maas and others, 1995), their $\mathrm{Pb}$-isotopic compositions are similar (fig. 3A). The mineralization at the Ruby Tuesday deposit thus occurs in several bed horizons in that area.

Sulfides from the massive sulfide deposits in the Moira Sound unit have scattered $\mathrm{Pb}$-isotopic compositions and plot 

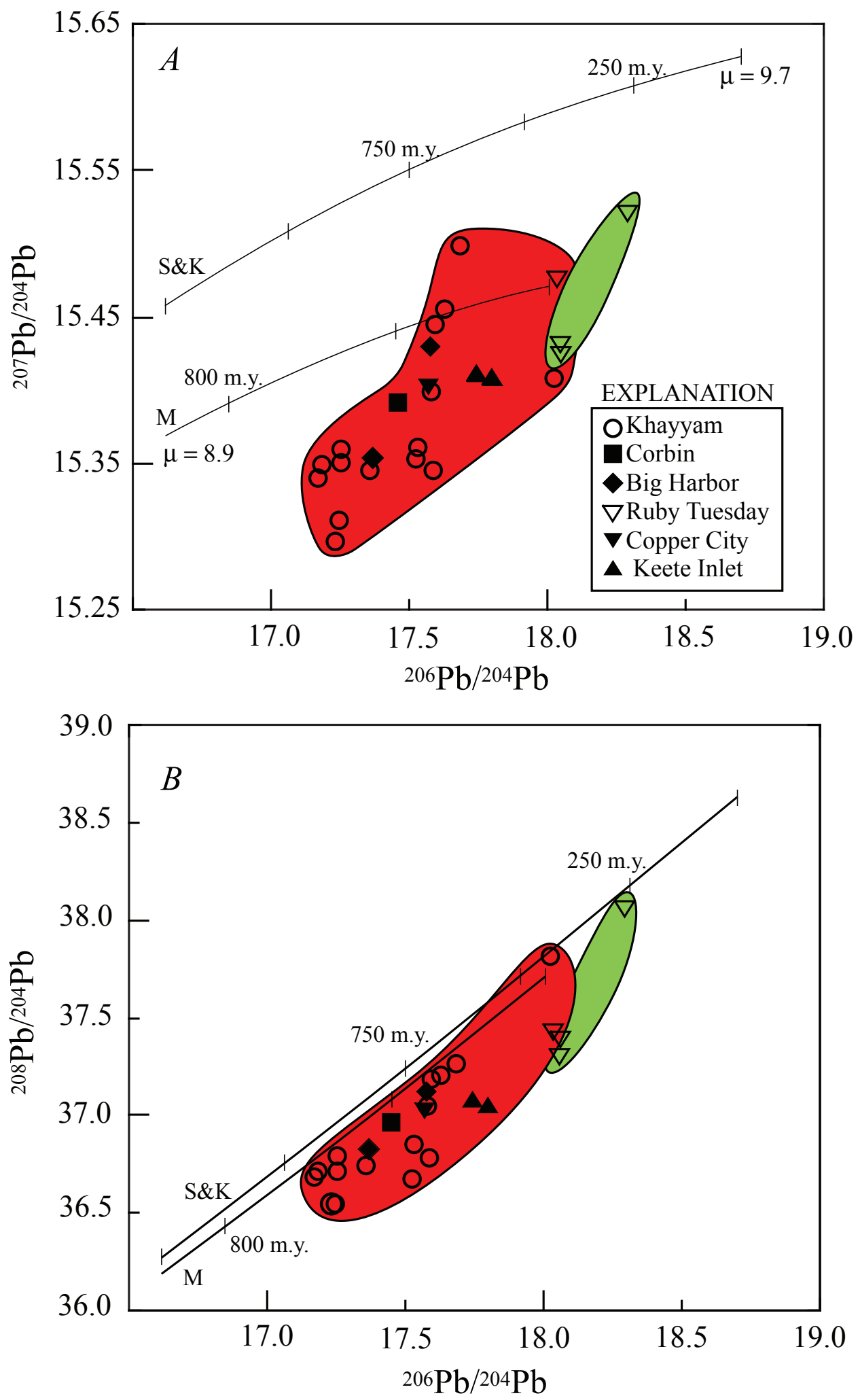

Figure 3. ${ }^{207} \mathrm{~Pb} /{ }^{204} \mathrm{~Pb}$ versus ${ }^{206} \mathrm{~Pb} /{ }^{204} \mathrm{~Pb}$ ratios $(A)$ and ${ }^{208} \mathrm{~Pb} / 204 \mathrm{~Pb}$ versus ${ }^{206} \mathrm{~Pb} /{ }^{204} \mathrm{~Pb}$ ratios $(B)$ for sulfides (bulk, leach, and residue) from massive sulfide deposits in the Wales Group (red field). Field for galena from the Ruby Tuesday (Fish Show) deposit and the Polymetal prospect (Kucinski, 1987) (green) is shown for reference. S\&K, average crustal Pb-evolution curve of Stacey and Kramers (1975); M, mantle-evolution curve from plumbotectonics model of Doe and Zartman (1979). 

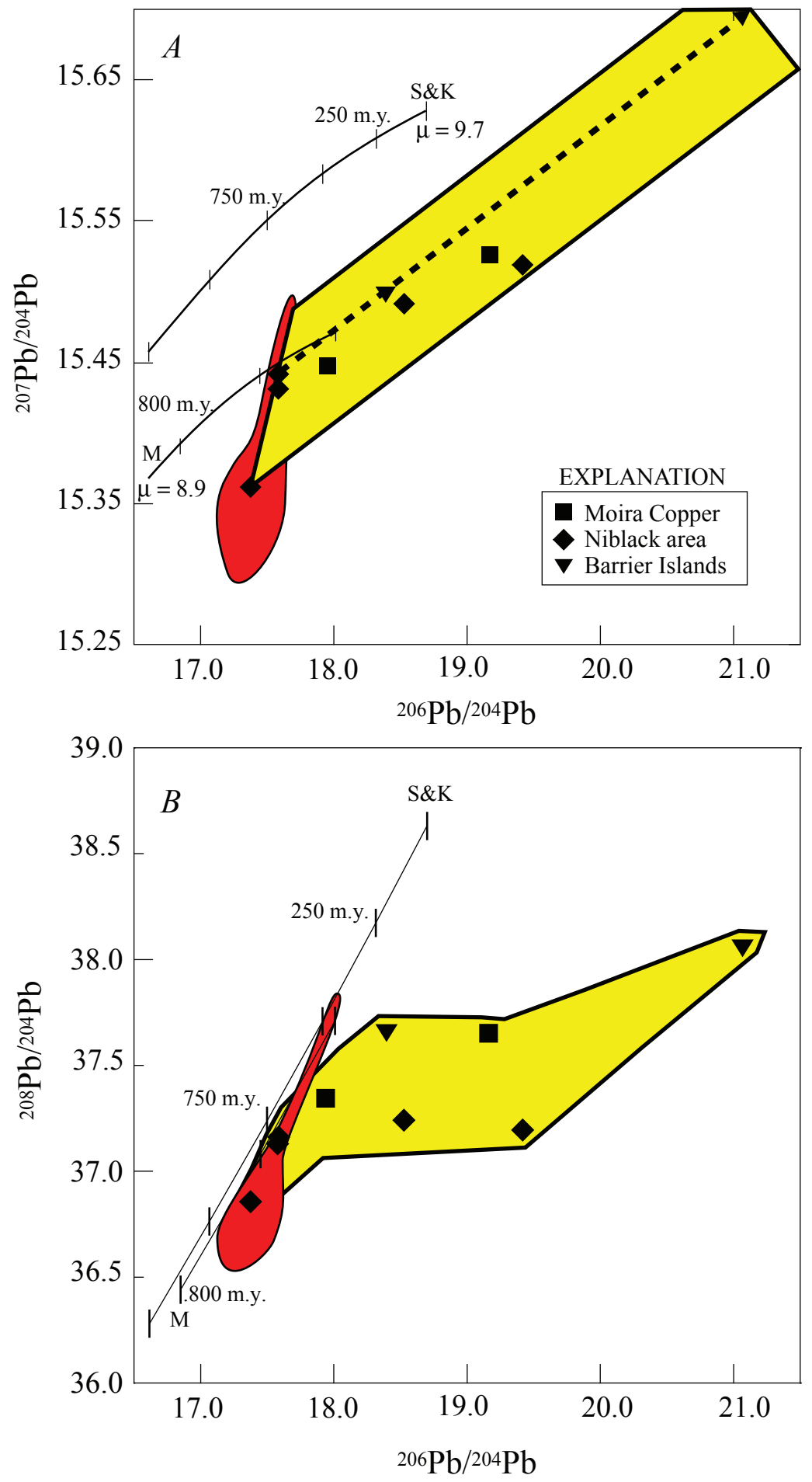

Figure 4. ${ }^{207} \mathrm{~Pb} /{ }^{204} \mathrm{~Pb}$ versus ${ }^{206} \mathrm{~Pb} /{ }^{204} \mathrm{~Pb}$ ratios $(A)$ and ${ }^{208} \mathrm{~Pb} / 204 \mathrm{~Pb}$ versus ${ }^{206} \mathrm{~Pb} /{ }^{204} \mathrm{~Pb}$ ratios $(B)$ for sulfides from massive sulfide deposits in the Moira Sound unit (yellow field). Field for sulfides from the Khayyam deposit (red) is shown for reference. Pb-evolution curves from figure 3. Regression line (dashed) in uranogenic $\mathrm{Pb}$ plot (fig. $4 A$ ) is calculated for samples from the Barrier Islands, Moira Copper, and Niblack deposits (slope, $\sim 0.070 \pm 0.015$; secondary isochron age, $952 \pm 30$ m.y.). Trendlines in figure $4 A$ are calculated to illustrate a two-stage $\mathrm{Pb}$ crustal history, assuming an average source for the massive sulfide deposits and generally contemporaneous mineralization. 

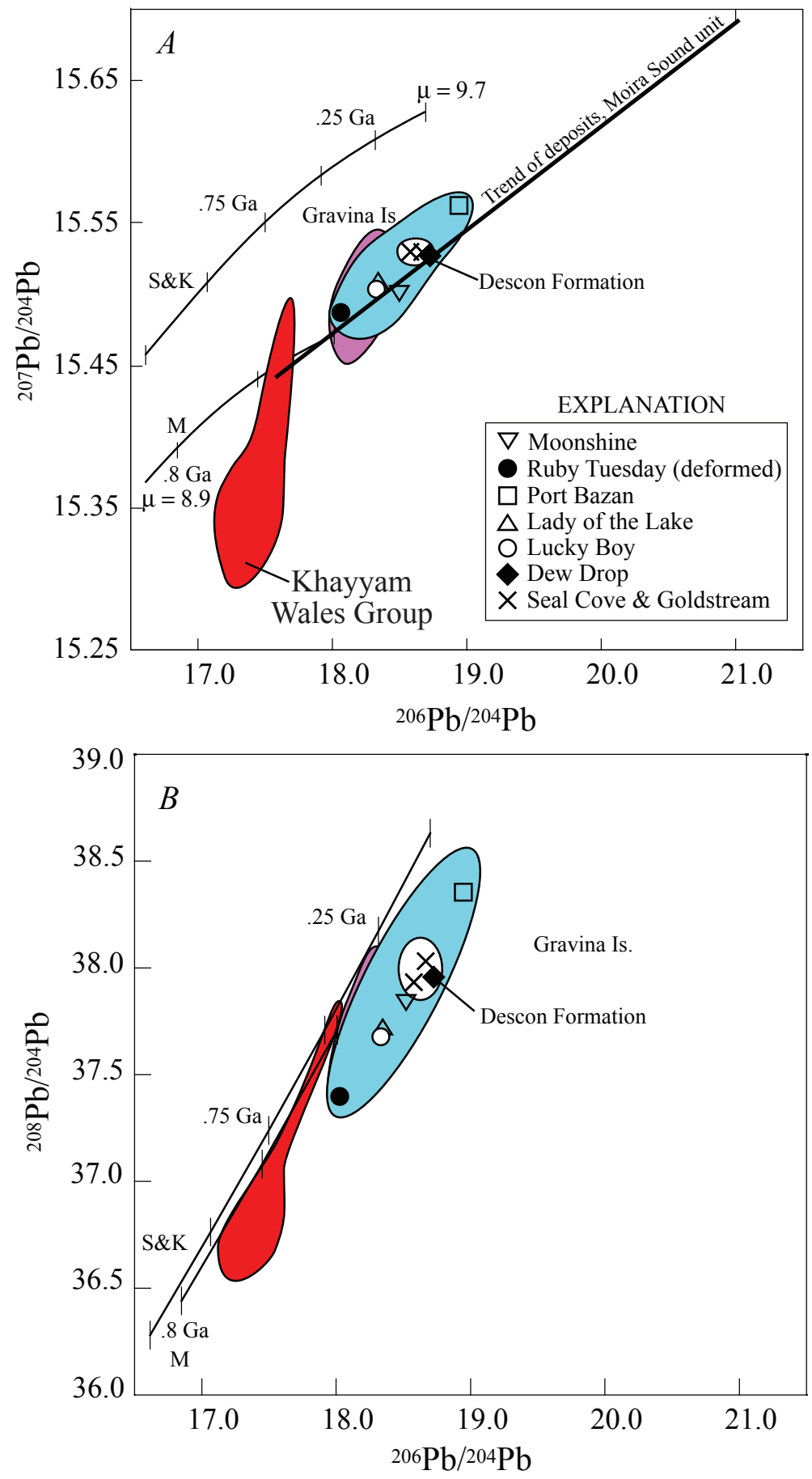

Figure 5. ${ }^{207} \mathrm{~Pb} /{ }^{204} \mathrm{~Pb}$ versus ${ }^{206} \mathrm{~Pb} /{ }^{204} \mathrm{~Pb}$ ratios $(A)$ and ${ }^{208} \mathrm{~Pb} / 204 \mathrm{~Pb}$ versus ${ }^{206} \mathrm{~Pb} /{ }^{204} \mathrm{~Pb}$ ratios $(B)$ for galena from polymetallic quartz-sulfide veins on Prince of Wales Island hosted by the Wales Group (blue field) and the Descon Formation, and on Gravina Island (white field). Field of sulfides from the Khayyam and Ruby Tuesday (Fish Show) deposits (red) and field of galena from the Polymetal prospect (purple; from Kucinski, 1987) are shown for reference. Pb-evolution curves from figure 3. Regression line (heavy), isotope trend of massive sulfide deposits in the Moira Sound unit. Data for galena-bearing polymetallic quartzsulfide veins plot within area subtended by parallel bounding lines that also enclose data for massive sulfide deposits in the Moira Sound unit. 
Table 1. Pb-isotopic data for sulfide minerals from massive sulfide deposits in the Wales Group, Prince of Wales Island and vicinity, southeastern Alaska.

[Sample numbers indicate drill hole and depth (in feet). Minerals: cp, chalcopyrite; gn, galena; po, pyrrhotite; py, pyrite; sp, sphalerite. Sample types: b, bulk dissolution; 1, leach; r, residue]

\begin{tabular}{|c|c|c|c|c|}
\hline Sample & Mineral & ${ }^{206} \mathrm{~Pb} /{ }^{204} \mathrm{~Pb}$ & ${ }^{207} \mathrm{~Pb} /{ }^{204} \mathrm{~Pb}$ & ${ }^{208} \mathrm{~Pb} /{ }^{204} \mathrm{~Pb}$ \\
\hline \multicolumn{5}{|c|}{ Khayyam deposit } \\
\hline JS-00-36A & $\mathrm{cp}, \mathrm{b}$ & 17.253 & 15.351 & 36.717 \\
\hline JS-00-36A & $\mathrm{cp}, 1$ & 17.249 & 15.360 & 36.796 \\
\hline JS-00-36A & $\mathrm{cp}, \mathrm{r}$ & 17.232 & 15.296 & 36.546 \\
\hline JS-00-36A & po, 1 & 17.240 & 15.312 & 36.547 \\
\hline JS-00-36A & po, $r$ & 17.178 & 15.350 & 36.718 \\
\hline JS-00-36A & po, b & 17.169 & 15.341 & 36.692 \\
\hline JS-00-36C & py, 1 & 17.594 & 15.446 & 37.192 \\
\hline JS-00-36C & py, $r$ & 17.581 & 15.346 & 36.791 \\
\hline JS-00-36C & py, b & 17.529 & 15.361 & 36.856 \\
\hline JS-00-36C & py, b & 17.626 & 15.456 & 37.207 \\
\hline JS-00-36C & $\mathrm{sp}, \mathrm{b}$ & 17.574 & 15.399 & 37.050 \\
\hline $\mathrm{JS}-00-36 \mathrm{C}$ & $\mathrm{sp}, \mathrm{b}$ & 17.678 & 15.499 & 37.265 \\
\hline JS-00-62F & $\mathrm{cp}, \mathrm{b}$ & 17.357 & 15.345 & 36.746 \\
\hline $\mathrm{JS}-00-62 \mathrm{~F}$ & $\mathrm{cp}, \mathrm{b}$ & 17.524 & 15.354 & 36.684 \\
\hline $\mathrm{JS}-00-62 \mathrm{~F}$ & $\mathrm{sp}, \mathrm{b}$ & 18.021 & 15.409 & 37.817 \\
\hline \multicolumn{5}{|c|}{ Corbin deposit } \\
\hline JS-00-56 & py, b & 17.458 & 15.391 & 36.971 \\
\hline \multicolumn{5}{|c|}{ Big Harbor deposit } \\
\hline JS-00-31D & $\mathrm{cp}, 1$ & 17.575 & 15.429 & 37.121 \\
\hline JS-00-31D & $\mathrm{cp}, \mathrm{r}$ & 17.368 & 15.354 & 36.829 \\
\hline \multicolumn{5}{|c|}{ Ruby Tuesday (Fish Show) deposit } \\
\hline RT-FS-MS & gn & 18.033 & 15.481 & 37.428 \\
\hline \multicolumn{5}{|c|}{ Copper City deposit } \\
\hline JS-00-55C & py, b & 17.569 & 15.402 & 37.019 \\
\hline \multicolumn{5}{|c|}{ Keete Inlet deposit } \\
\hline JS-00-53A & py, 1 & 17.740 & 15.411 & 37.078 \\
\hline $\mathrm{JS}-00-53 \mathrm{~A}$ & py, $\mathrm{r}$ & 17.798 & 15.408 & 37.050 \\
\hline
\end{tabular}

as a broad band on uranogenic (slope, $\sim 0.070 \pm 0.015$; secondary isochron age, $\sim 952 \pm 30$ m.y.) and thorogenic $\mathrm{Pb}$ diagrams (figs. $4 A, 4 B$; table 2). Data for this younger group of deposits overlap the trend for massive sulfide deposits in the Wales Group but extend to significantly more radiogenic $\mathrm{Pb}$-isotopic values. The most radiogenic compositions in this group are for the Barrier Islands deposit (table 2), which may have incorporated evolved lead from metasedimentary rocks. In the Niblack deposit, the least radiogenic values are comparable to those in the Khayyam deposit, but significantly, the most radiogenic values in the Niblack deposit from the Khayyam trend toward higher ${ }^{206} \mathrm{~Pb} /{ }^{204} \mathrm{~Pb}$ ratios. Moreover, the $\mathrm{Pb}$-isotopic ratios of sulfides from the massive sulfide deposits in the Moira Sound unit plot on a different, shallower trend $\left({ }^{206} \mathrm{~Pb} /{ }^{204} \mathrm{~Pb}=17.375-\right.$ $19.418,{ }^{207} \mathrm{~Pb} /{ }^{204} \mathrm{~Pb}=15.361-15.519,{ }^{208} \mathrm{~Pb} /{ }^{204} \mathrm{~Pb}=36.856-$ 37.241 ; figs. $4 A$, $4 B$; table 2 ) relative to the steep slope defined by the massive sulfide deposits in the Wales Group.

Galena from the polymetallic quartz-sulfide veins on Prince of Wales Island occurs in both deformed and undeformed vein types. Notably, the data do not define a distinct isotopic group but overlap $\mathrm{Pb}$-isotopic compositions of the massive sulfides. $\mathrm{Pb}$-isotopic values of the veins vary widely $\left({ }^{206} \mathrm{~Pb} /{ }^{204} \mathrm{~Pb}=18.339-18.946\right.$, ${ }^{207} \mathrm{~Pb} /{ }^{204} \mathrm{~Pb}=15.447-15.561,{ }^{208} \mathrm{~Pb} /{ }^{204} \mathrm{~Pb}=37.358-38.354$; figs. $5 A, 5 B$; table 3 ), straddling the slope defined by the massive sulfides in the Moira sound unit. 
Table 2. Pb-isotopic data for sulfide minerals from massive sulfide deposits in the Moira Sound unit, Prince of Wales Island and vicinity, southeastern Alaska.

[Sample numbers indicate drill hole and depth (in feet). Minerals: cp, chalcopyrite; gn, galena; po, pyrrhotite; py, pyrite; sp, sphalerite. Sample types: b, bulk dissolution; 1, leach; r, residue]

\begin{tabular}{|c|c|c|c|c|}
\hline Sample & Mineral & ${ }^{206} \mathrm{~Pb} /{ }^{204} \mathrm{~Pb}$ & ${ }^{207} \mathrm{~Pb} /{ }^{204} \mathrm{~Pb}$ & ${ }^{208} \mathrm{~Pb} /{ }^{204} \mathrm{~Pb}$ \\
\hline \multicolumn{5}{|c|}{ Moira deposit } \\
\hline MC-MS & $\mathrm{cp}, \mathrm{b}$ & 19.162 & 15.527 & 37.652 \\
\hline MC-MS2 & py, b & 17.939 & 15.448 & 37.345 \\
\hline \multicolumn{5}{|c|}{ Niblack (Dama) deposit } \\
\hline LO-61/573 & $\mathrm{cp}, 1$ & 19.418 & 15.519 & 37.195 \\
\hline LO-61/573 & $\mathrm{cp}, \mathrm{r}$ & 18.526 & 15.491 & 37.241 \\
\hline \multicolumn{5}{|c|}{ Niblack (Lookout Mountain) deposit } \\
\hline LO-99/367 & $\mathrm{cp}, 1$ & 17.578 & 15.431 & 37.130 \\
\hline LO-99/367 & $\mathrm{cp}, \mathrm{r}$ & 17.375 & 15.361 & 36.856 \\
\hline LO-99/367 & py, b & 17.586 & 15.442 & 37.161 \\
\hline \multicolumn{5}{|c|}{ Barrier Islands deposit } \\
\hline RAAK-0044 & py, b & 21.068 & 15.688 & 38.074 \\
\hline $478-151$ & po, b & 18.396 & 15.498 & 37.674 \\
\hline
\end{tabular}

Traditional estimates for $\mathrm{Pb}$-isotopic model ages (Stacey and Kramers, 1975) of the massive sulfide deposits are not meaningful because the predominant Fe sulfide minerals are unlikely to have $\mathrm{U} / \mathrm{Pb}$ and $\mathrm{Th} / \mathrm{Pb}$ ratios as low as in galena. Because most of the massive sulfide deposits are galena poor, their $\mathrm{Pb}$-isotopic compositions may not have remained unchanged after initial mineralization. Data for galena samples from the Ruby Tuesday deposit (Fish Show deposit and Polymetal prospect), moreover, yield unreasonably young model ages (<197 m.y.), comparable to those of the polymetallic quartz-sulfide veins (<154 m.y.).

On a plot of ${ }^{208} \mathrm{~Pb} /{ }^{204} \mathrm{~Pb}$ versus ${ }^{206} \mathrm{~Pb} /{ }^{204} \mathrm{~Pb}$ ratios (fig. $3 B$ ), most of the massive sulfide deposits in the Wales Group plot off the average crustal $\mathrm{Pb}$-evolution curve (Stacey and Kramers, 1975), with higher ${ }^{206} \mathrm{~Pb} /{ }^{204} \mathrm{~Pb}$ ratios for a given ${ }^{208} \mathrm{~Pb} /{ }^{204} \mathrm{~Pb}$ ratio. $\mathrm{Pb}$-isotopic compositions of these deposits straddle the mantle curve (plumbotectonics model: ${ }^{238} \mathrm{U} / 204 \mathrm{~Pb}=\mu \sim 8.9$; Doe and Zartman, 1979) for thorogenic $\mathrm{Pb}$ (fig. 3B), although some of the sulfides have lower $\mu$ values than the mantle on the uranogenic $\mathrm{Pb}$ diagram (fig. $3 A$ ). The uranogenic $\mathrm{Pb}$ data show no evidence of a long residence time in the upper crust (or in the lower crust, as indicated by the thorogenic $\mathrm{Pb}$ diagram), but the broad distribution of $\mathrm{Pb}$-isotopic values indicates contributions from $\mathrm{Pb}$ sources with different $\mu$ values. On the uranogenic $\mathrm{Pb}$ diagram, the higher $\mu$ values of the massive sulfide deposits in the Wales Group approach those typical of average crust or of orogenic rocks generated at convergent margins ( $\mu \sim 9.74)$. Traditionally, in both modern and ancient hydro- thermal systems, such isotopic distributions are attributed to mixing of mantle-derived lead (for example, from basalts) and crustal lead (for example, from subducted pelagic sediment).

Sulfide samples from the massive sulfide deposits in the Moira Sound unit have also been recrystallized and metamorphosed, and so their $\mathrm{U} / \mathrm{Pb}$ and $\mathrm{Th} / \mathrm{Pb}$ systems are likely disturbed. Several sulfide samples (R.A. Ayuso, unpub. data, $2005)$ have high $\mathrm{Pb}$ contents $(>120 \mathrm{ppm})$ but low $\mathrm{U}(<1 \mathrm{ppm})$ and Th $(<1 \mathrm{ppm})$ contents. Such data cannot be used reliably for geochronology or to calculate the original $\mathrm{Pb}$-isotopic compositions at the time of mineralization. Nevertheless, the generally low $\mu$ values $(<1)$ and ${ }^{232} \mathrm{Th} /{ }^{204} \mathrm{~Pb}$ ratios $(<5)$ calculated from these data indicate that the radiogenic $\mathrm{Pb}$ generated by the decay of $U$ and Th since crystallization did not appreciably affect the original $\mathrm{Pb}$-isotopic compositions. Thus, in the following sections, we assume that the $\mathrm{Pb}$-isotopic ratios of the sulfide minerals represent reasonable estimates of their original $\mathrm{Pb}$-isotopic compositions at the time of sea-floor or sub-sea-floor mineralization.

Calculated $\mathrm{Th} / \mathrm{U}$ ratios of the massive sulfide deposits in the Wales Group are $~ 5.2$, in contrast to those of the massive sulfide deposits in the Moira Sound unit, which are much lower ( 0.06). These exceptionally low $\mathrm{Th} / \mathrm{U}$ ratios in the younger group of deposits are unlike those in most crustal rocks (typically, $\sim 3-4$ ). One possible explanation is that these low $\mathrm{Th} / \mathrm{U}$ ratios reflect preferential leaching of radiogenic ${ }^{206} \mathrm{~Pb}$ (instead of older ${ }^{208} \mathrm{~Pb}$ ) from the Wales Group or the Moira Sound unit during mineralization. 
Table 3. Pb-isotopic data for galena from polymetallic quartz-sulfide veins, Prince of Wales Island and vicinity, southeastern Alaska.

[Sample numbers indicate drill hole and depth (in feet)]

\begin{tabular}{|c|c|c|c|c|}
\hline Sample & Deposit & ${ }^{206} \mathrm{~Pb} /{ }^{204} \mathrm{~Pb}$ & ${ }^{207} \mathrm{~Pb} /{ }^{204} \mathrm{~Pb}$ & ${ }^{208} \mathrm{~Pb} /{ }^{204} \mathrm{~Pb}$ \\
\hline \multicolumn{5}{|c|}{ Wales Group } \\
\hline 84AGK052B & Moonshine (deformed vein) & 18.511 & 15.503 & 37.846 \\
\hline JS-00-49B & Ruby Tuesday (deformed vein) & 18.036 & 15.476 & 37.417 \\
\hline 1625 & Port Bazan & 18.946 & 15.561 & 38.354 \\
\hline 5824 & Lady of the Lake & 18.347 & 15.508 & 37.699 \\
\hline $83 \mathrm{AGK}-106 \mathrm{C}$ & Lucky Boy & 18.339 & 15.502 & 37.673 \\
\hline \multicolumn{5}{|c|}{ Descon Formation } \\
\hline 5354 & Dew Drop & 18.726 & 15.526 & 37.956 \\
\hline \multicolumn{5}{|c|}{ Gravina belt } \\
\hline 8152 & Goldstream & 18.666 & 15.525 & 38.031 \\
\hline $\mathrm{K}-8368$ & Seal Cove & 18.579 & 15.525 & 37.932 \\
\hline
\end{tabular}

\section{Discussion}

\section{Lead Sources: Massive Sulfide Deposits in the Wales Group}

The VMS deposits on Prince of Wales Island are thought to have formed coevally with their host volcanic rocks, which, on the basis of trace-element variations, can be linked to relatively primitive, unevolved source compositions (Karl and others, 2003). Consistent with such likely lead sources, the $\mathrm{Pb}$ isotopes in these rocks would also have evolved with a similar history, without long-term residence in the crust. Below, we discuss the interpretation that because of the general depletion in ${ }^{207} \mathrm{~Pb} /{ }^{204} \mathrm{~Pb}$ (figs. $3 A, 4 A$ ), the most likely lead sources of these VMS deposits are those associated with oceanic volcanic rocks. Rocks hosting the deposits thus may have resided in intraoceanic tectonic settings where the mantle was the predominant contributor of metals.

Identification of the exact type of mantle involved in the formation of the VMS deposits on Prince of Wales Island on the basis of $\mathrm{Pb}$-isotopic compositions, however, is equivocal. Direct estimates of mantle composition are not meaningful because the island was affected by regional metamorphism that resulted in mineral recrystallization in areas of high-grade metamorphism (for example, at the Khayyam deposit), and significant element redistribution in the host rocks. Moreover, the deposits are $\mathrm{Pb}$ poor (for example, galena is rare) and dominated by Fe sulfides.

$\mathrm{Pb}$-isotopic compositions of the massive sulfide deposits in the Wales Group resemble those of mantle-derived rocks and hydrothermal deposits in oceanic settings (fig. 6). Possible modern tectonic analogs and associated sources include ocean ridges worldwide (for example, White and others, 1987; Ito and others, 1987; Hofmann, 1997), island and intraoceanic arcs in the Pacific Ocean that are situated entirely on oceanic crust (for example, the Izu-Bonin-Marianas arc; Meijer, 1976; Stern and Ito, 1983; see compilation by Elliott and others, 1997), and rifted intraoceanic arcs (for example, the Sumisu rift; Hochstaedter and others, 1990). The Pb-isotopic compositions of the hydrothermal sulfides related to such ocean ridges (for example, Brevart and others, 1981; Fouquet and Marcoux, 1995; Cousens and others, 2002) and backarc basins (Godfrey and others, 1994; Verati and others, 1994; Halbach and others, 1997; Stuart and others, 1999) closely match those of their host basaltic rocks.

Paleozoic tectonic analogs to the VMS deposits on Prince of Wales Island (fig. 7) include the mainly Carboniferous Besshi-type (oceanic-mantle related) deposits in Japan (Sato and Sasaki, 1980), the Devonian Shasta deposits related to a primitive island arc in California (Doe and others, 1985), and the Lower Paleozoic (mostly Ordovician through Silurian) deposits related to primitive island arcs and arc rifting in Newfoundland and the Eastern Townships of Quebec (Swinden and Thorpe, 1984; Cumming and Krstic, 1987; Swinden, 1996; Pollock and Wilton, 2001). The Paleozoic massive sulfide deposits, which are among those with the most primitive $\mathrm{Pb}$-isotopic compositions, have been used to estimate the composition of cogenetic Devonian (Shasta) and Ordovician (Newfoundland) mantle (fig. 7).

The mantle associated with modern oceanic basalts is heterogeneous. At the scale of ocean basins (Indian, Pacific, and Atlantic), for example, basaltic rocks have distinct $\mathrm{Pb}$-isotopic compositions (see review by Hofmann, 1997). Calculated mantle $\mathrm{Pb}$-isotopic compositions for selected basalts, corrected for $\mathrm{Pb}$ evolution and adjusted to the age of the massive sulfide deposits in the Wales Group by using the average crustal 
Pb-evolution curve (Stacey and Kramers, 1975), are plotted in figure 8 . The $\mathrm{Pb}$-isotopic compositions of basalts from the Pacific and Indian Oceans (for example, Hamelin and Allegre, 1985), the Marianas island arc (for example, Meijer, 1976), and Hawaii (for example, Stille and others, 1983), when adjusted in this manner, significantly overlap those of the VMS deposits on Prince of Wales Island.

The $\mathrm{Pb}$-isotopic compositions of some of the Indian Ocean basalts (for example, from the Southwest Indian Ridge) have been attributed to contamination by ancient continental crust or sediment (Dupre and Allegre, 1983) or to stranded continental lithosphere (Mahoney and others, 1992). For plume-related Hawaiian basalts, recycling of old and hydrothermally altered oceanic crust and lithosphere has been suggested (Lassiter and Hauri, 1998). As a general illustration, a plot of ${ }^{207} \mathrm{~Pb} /{ }^{204} \mathrm{~Pb}$ versus ${ }^{206} \mathrm{~Pb} /{ }^{204} \mathrm{~Pb}$ ratios indicates that a combination of relatively unradiogenic basalt and radiogenic sediment can account for the $\mathrm{Pb}$-isotopic variations observed in the massive sulfide deposits in the Wales Group (fig. 7). Our estimates indicate that a contribution of $<<25$ percent $\mathrm{Pb}$ from pelagic sediment would be adequate, although a significantly lower contribution ( $<5$ percent) would be needed if the sediment had a $\mathrm{Pb}$ content more typically of 20 to $50 \mathrm{ppm}$ (for example, Plank and Langmuir, 1998) instead of the 20 ppm used in calculations to establish the maximum contribution from pelagic sediment. To choose among the various possible oceanic sources and tectonic settings for the massive sulfide deposits in the Wales Group is beyond the scope of this study. At present, we emphasize that the lead source of these deposits was predominantly the mantle, that some reworked arc material or recycled older, hydrothermally altered oceanic crust (including pelagic sediment) may have been involved in generating the trend toward somewhat higher ${ }^{207} \mathrm{~Pb} /{ }^{204} \mathrm{~Pb}$ ratios, and that the likely tectonic setting during massive sulfide mineralization was not on ancient continental crust (fig. 7).

\section{Lead Sources: Massive Sulfide Deposits in the Moira Sound Unit}

On a plot of ${ }^{207} \mathrm{~Pb} /{ }^{204} \mathrm{~Pb}$ versus ${ }^{206} \mathrm{~Pb} /{ }^{204} \mathrm{~Pb}$ ratios (fig. $4 A$ ), eight of the nine data points representing analyses of samples from massive sulfides in the Moira Sound unit fall on a broad band except the one for the Niblack deposit, which has the lowest ratios. This discrepancy may be due to analytical error.

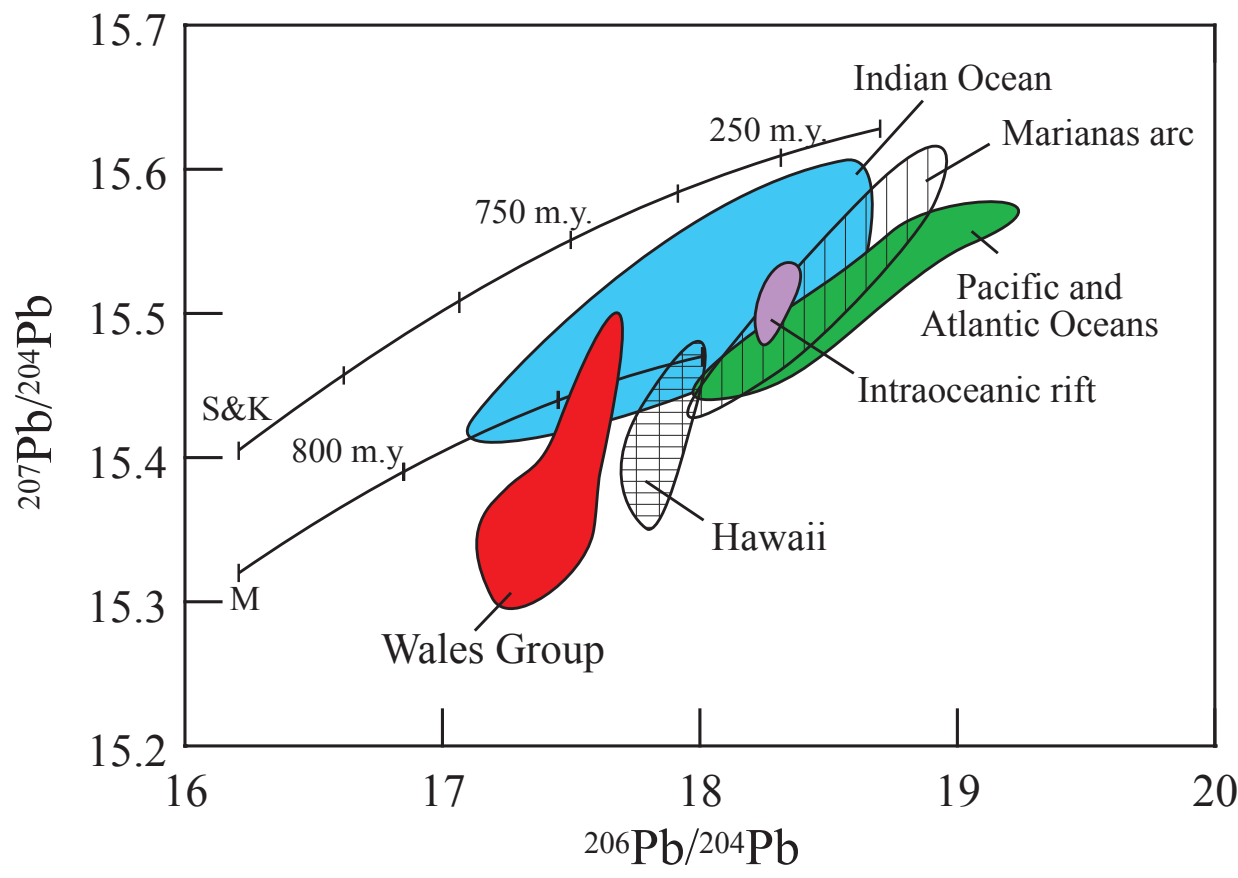

Figure 6. ${ }^{207} \mathrm{~Pb} /{ }^{204} \mathrm{~Pb}$ versus ${ }^{206} \mathrm{~Pb} /{ }^{204} \mathrm{~Pb}$ ratios for sulfides from massive sulfide deposits in the Wales Group and young volcanic rocks from the Pacific Ocean (Ito and others, 1987; White and others, 1987; Verati and others, 1994; Fouquet and Marcoux, 1995; Cousens and others, 2002), the Atlantic Ocean (Hamelin and Allegre, 1985; Ito and others, 1987; White and others, 1987; Stuart and others, 1999), and the Indian Ocean (Dupre and Allegre, 1983; Hamelin and Allegre, 1985; Mahoney and others, 1992), as well as for basalt from the Hawaiian plume (Stille and others, 1983; Roden and others, 1994; Bennett and others, 1996; Lassiter and Hauri, 1998; Norman and Garcia, 1999), backarc basins (Halbach and others, 1997), primitive island arcs in the Marianas (Meijer, 1976; Stern and Ito, 1983; Elliot and others, 1997; Gribble and others, 1998; Taylor and Nesbitt, 1998), and associated intraoceanic-rift volcanic rocks (Sumisu Rift; Hochstaedter and others, 1990). 
To distinguish lead sources within the spread of Pb-isotopic compositions, several likely geologic histories can be illustrated. The parallel trend lines in figure $4 A$ enclose the highest ${ }^{207} \mathrm{~Pb} /{ }^{204} \mathrm{~Pb}$ ratios for a given ${ }^{206} \mathrm{~Pb} /{ }^{204} \mathrm{~Pb}$ ratio in the massive sulfide deposits in the Moira Sound unit, along with a line that is low enough to include all the data. The general slope $(m=0.070 \pm 0.015)$ of this band is consistent with a two-stage crustal history for the lead, a common average lead source, and possibly, a common mineralization age for the deposits. Scatter in the data may indicate that some of the samples were mineralized at slightly different times but from a source of approximately the same average age.

We note that some data points for the Niblack deposits fall on the trend for the older group of deposits (fig. 4A), as well as others that significantly depart from this trend and plot along the trend for the younger group of deposits (Barrier Islands and Moira Copper). Significantly, no data points for the younger group of deposits plot to the left of the trend, although their radiogenic ${ }^{206} \mathrm{~Pb} /{ }^{204} \mathrm{~Pb}$ ratios are lower than those of the older group of deposits on the plots of ${ }^{207} \mathrm{~Pb} /{ }^{204} \mathrm{~Pb}$ versus ${ }^{206} \mathrm{~Pb} /{ }^{204} \mathrm{~Pb}$ ratios (fig. $4 A$ ) and ${ }^{208} \mathrm{~Pb} /{ }^{204} \mathrm{~Pb}$ versus ${ }^{206} \mathrm{~Pb} /{ }^{204} \mathrm{~Pb}$ ratios (fig. $4 B$ ). The overall linear relation of data for the massive sulfide deposits in the Moira Sound unit thus implies that the Barrier Islands, Moira Copper, and Niblack deposits were mineralized contemporaneously and that their lead sources were older, approximately coeval rocks (for example, Late Proterozoic through Cambrian?), in addition to other, more radiogenic rocks in the fluid-reaction path that would account for the variation in ${ }^{206} \mathrm{~Pb} /{ }^{204} \mathrm{~Pb}$ ratios. Such a close link to older source rocks is particularly evident for the Niblack deposit, which notably is hosted by felsic metavolcanic and tuffaceous metasedimentary rocks that resemble the lithologic sequence in the Wales Group (Gehrels and Berg, 1992; Maas and others, 1995). Detrital zircons dated by U-Pb

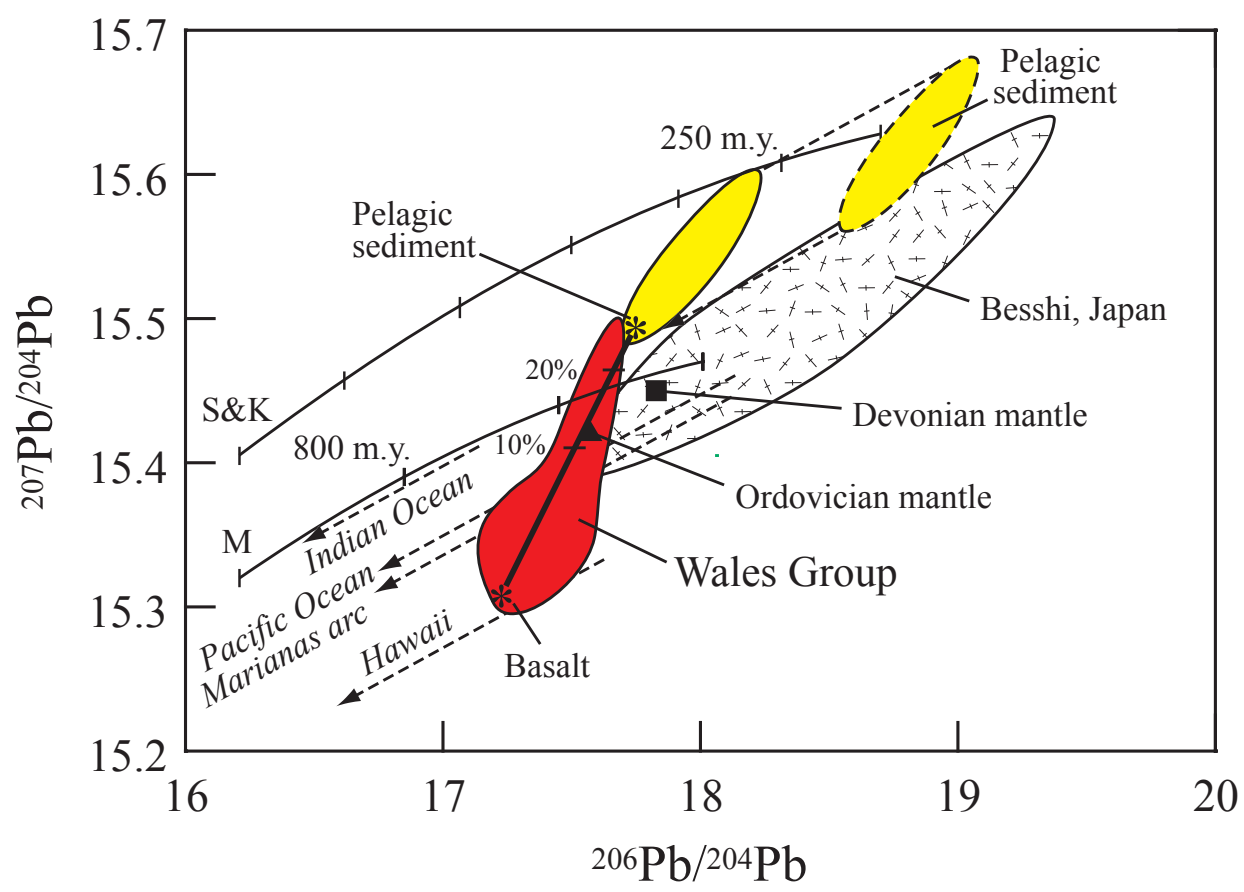

Figure 7. Estimated ${ }^{207} \mathrm{~Pb} /{ }^{204} \mathrm{~Pb}$ versus ${ }^{206} \mathrm{~Pb} /{ }^{204} \mathrm{~Pb}$ ratios for Ordovician mantle from primitive intraoceanic arcs in Newfoundland (Swinden and Thorpe, 1984; Swinden, 1996) and for Devonian mantle from a primitive island arc associated with massive sulfide deposits in the Klamath Mountains, Calif. (Shasta; Doe and others, 1985). Fields for pelagic sediment from the Pacific Ocean (Marianas arc, Meijer, 1976); for basalts from the Marianas arc, the Hawaiian plume (Koolau caldera), and the Pacific and Indian Oceans (estimated age, 550 m.y., using average crustal Pb-evolution curve of Stacey and Kramers, 1975; see fig. 6); and for Besshi-type massive sulfide deposits in Japan (Sato and Sasaki, 1980) are shown for reference. Dashed lines illustrate magnitude of age correction toward less radiogenic compositions. Mixing line was calculated between end members of pelagic sediment and basalt (asterisks) at $\sim 550$ m.y., assuming the following parameters for pelagic-sediment content ( 20 ppm Pb, $\left.{ }^{206} \mathrm{~Pb} /{ }^{204} \mathrm{~Pb} \sim 17.8,{ }^{207} \mathrm{~Pb} /{ }^{204} \mathrm{~Pb} \sim 15.5\right)$ and basalts $\left(\sim 2 \mathrm{ppm} \mathrm{Pb},{ }^{206} \mathrm{~Pb} /{ }^{204} \mathrm{~Pb} \sim 17.2\right.$, ${ }^{207} \mathrm{~Pb} /{ }^{204} \mathrm{~Pb} \sim 15.3$ ). Two tickmarks on heavy line represent additions of 10 and 20 percent pelagic sediment to basalt. 
methods at $595 \pm 20$ m.y. (Gehrels and others, 1996), together with recent detailed geologic mapping (S.M. Karl and others, unpub. data, 2006), however, indicate that the host rocks of the Niblack deposit belong to the Moira Sound unit and not to the Wales Group (S.M. Karl and others, unpub. data, 2006).

Assuming that the slope $(\sim 0.070 \pm 0.015)$ of uranogenic $\mathrm{Pb}$ data for the massive sulfides in the Moira Sound unit is meaningful, average source ages can be estimated. For example, an average source age of about 525 m.y. can be calculated if the deposits are assumed to be Early Ordovician ( 480 m.y.). Notably, an age of about 484 m.y. coincides with the date of amphibolite-grade regional metamorphism in the Wales Group (Herreid and others, 1978; Eberlein and others, 1983; Gehrels and Saleeby, 1987). Considering a younger mineralization age, such as Late Silurian $(\sim 417$ m.y.), would result in a slightly older ( 589 m.y.) average lead source. Although the significance of possible source-age calculations for the massive sulfide deposits in the Moira Sound unit should remain equivocal because of the relatively limited range of isotopic ratios and imperfectly defined isotopic slope for these deposits, it is geologically reasonable that their source region included lead from older rocks, possibly resembling those of the underlying Wales Group and its contained massive sulfide deposits. Our $\mathrm{Pb}$-isotopic data for all these deposits are mainly reflect the contrasting underlying host rock sequences and their varying mineralization ages. Postore metamorphism probably had only a limited effect on the $\mathrm{Pb}$-isotopic compositions of the deposits.

\section{Lead Sources: Polymetallic Quartz-Sulfide Veins}

$\mathrm{Pb}$-isotopic compositions of the galena-bearing polymetallic quartz-sulfide veins on Prince of Wales Island and vicinity (fig. 1) do not fall in a discrete field but lie within the area subtended by the parallel bounding lines that enclose the data points for the younger group of deposits (figs. $5 A, 5 B$ ) and slightly overlap those of the older deposits (for example, the Ruby Tuesday), although the compositions mostly indicate higher ${ }^{206} \mathrm{~Pb} /{ }^{204} \mathrm{~Pb}$ ratios for a given ${ }^{207} \mathrm{~Pb} /{ }^{204} \mathrm{~Pb}$ ratio (fig. $5 A)$. In contrast to the massive sulfide deposits in the Moira Sound unit, the Devonian quartz-sulfide veins intruded Late Proterozoic through Cambrian schist and gneiss of the Wales Group, as well as the Ordovician through Early Silurian Descon Formation (for example, at the Dew Drop deposit). Some veins cutting rocks of the Wales Group are deformed (for example, at the Moonshine deposit), whereas others show

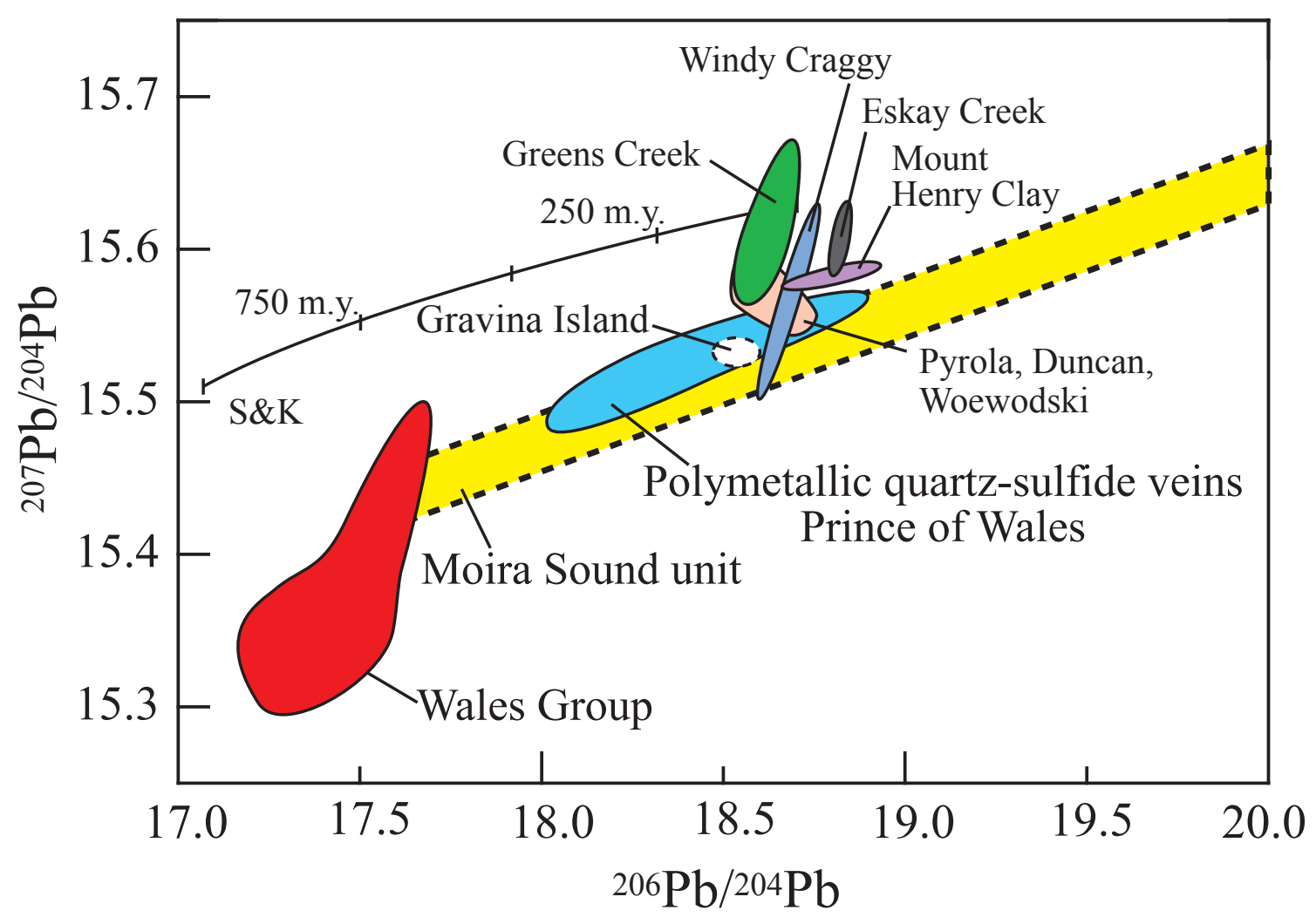

Figure 8. ${ }^{207} \mathrm{~Pb} / 204 \mathrm{~Pb}$ versus ${ }^{206} \mathrm{~Pb} /{ }^{204} \mathrm{~Pb}$ ratios for sulfides from massive sulfide deposits in the Wales Group and the Moira Sound unit, polymetallic quartz-sulfide veins on Prince of Wales Island, and other deposits and veins in the Alexander terrane. Data sources: Kucinski (1987), Godwin and others (1988), Gacetta and Church (1989), Childe (1996), Newberry and Brew (1997), Peter and Scott (1999), and W. Premo (written commun., 2001). 
no deformation (for example, at the Lucky Boy deposit), suggesting that the veins encompass a range of mineralization ages. As a group, however, the veins sampled for this study from the Wales Group are noteworthy in their similar $\mathrm{Pb}$-isotopic compositions, regardless of possible differences in mineralization age. $\mathrm{Pb}$-isotopic compositions emphasize the close genetic linkage between some massive sulfide deposits (for example, the Polymetal prospect and the Fish Show prospect in the Ruby Tuesday area) and quartz-sulfide veins (for example, at the Moonshine deposit). We note that even the stratabound mineralization at the Ruby Tuesday deposit (Polymetal prospect) has stringers crosscutting layers that have been interpreted as representing metamorphic remobilization (Kucinski, 1987). Moreover, the $\mathrm{Pb}$-isotopic compositions of the Moira Copper and Niblack deposits also resemble those of nearby veins (at the Lady of the Lake and Lucky Boy deposits), again attesting to a similar lead source. Considering that the $\mathrm{Au}$ - and $\mathrm{Cu}$-bearing quartz veins in the area are likely linked to regional Devonian metamorphism and deformation (see Haeussler and others, this volume), the mineralization age is constrained to $<410$ m.y. (Karl and others, 2005). In addition, lead in the veins may consist of a component from mineralizing vein fluids, together with radiogenic $\mathrm{Pb}$ that was leached from footwall rocks along the fluid-reaction path. Model ages of the veins are too young (including future ages) and scattered to yield reliable source-age estimates. Despite the presumed age differences of a few hundred million years among the veins, rocks of the Wales Group and Moira Sound unit, and associated massive sulfide deposits, the age differences are unlikely to have caused significant differences in ${ }^{207} \mathrm{~Pb} / 204 \mathrm{~Pb}$ ratios because of the minimal increase in ${ }^{207} \mathrm{~Pb}$ from the decay of ${ }^{235} \mathrm{U}$ during this period.

Polymetallic quartz-sulfide veins in the vicinity of the massive sulfide deposits show a similar trend on the plot of ${ }^{208} \mathrm{~Pb} /{ }^{204} \mathrm{~Pb}$ versus ${ }^{206} \mathrm{~Pb} /{ }^{204} \mathrm{~Pb}$ ratios (fig. $3 B$ ) to that for the sulfide deposits in the Wales Group. The veins have higher ${ }^{208} \mathrm{~Pb} / 204 \mathrm{~Pb}$ and ${ }^{206} \mathrm{~Pb} /{ }^{204} \mathrm{~Pb}$ ratios, slightly shifted from those of the massive sulfide deposits and consistent with the younger age of the veins. Data points for the veins also lack the flat slopes of those for the massive sulfide deposits in the Moira Sound unit, a feature also interpreted as consistent with an origin by leaching and mobilization of lead from rocks of the Wales Group.

\section{Regional Comparison: Prince of Wales Island and Other Terranes in Southeastern Alaska}

In this section, we compare the $\mathrm{Pb}$-isotopic compositions of the VMS and quartz-sulfide veins on Prince of Wales Island with those of other deposits and veins in neighboring terranes. The tectonic evolution of southeastern Alaska and, particularly, of the Alexander terrane has been the subject of many recent geologic and geochemical studies (for example, Gehrels and Saleeby, 1987; Samson and others, 1989; S.M. Karl and others, unpub. data, 2006). The Gravina Belt, an overlap sequence between the outboard Alexander terrane and the inboard ances- tral North American margin (Berg and others, 1972), together with the Stikinia terrane, is also thought to consist mostly of juvenile, mantle-derived crust, on the basis of Nd-isotopic studies (Samson and others, 1989, 1991). Moreover, these studies indicate that the crustal infrastructure of the Alexander terrane is heterogeneous, that much of the crust is juvenile or mantlederived instead of older or reworked crust, and that a likely tectonic setting is an intraoceanic-arc environment.

General features of the $\mathrm{Pb}$-isotopic compositions of the VMS deposits and quartz-sulfide veins are summarized below, but further details are beyond the scope of this study. Two large Triassic VMS deposits (Greens Creek, Alaska, and Windy Craggy, British Columbia) occur in the Alexander terrane north of Prince of Wales Island, as well as another large VMS deposit (Eskay Creek, British Columbia) in the Stikinia terrane (fig. 8). ${ }^{207} \mathrm{~Pb} /{ }^{204} \mathrm{~Pb}$ ratios in the Greens Creek are higher than the average crustal $\mathrm{Pb}$-evolution curve of Stacey and Kramers (1975) (W. Premo, written commun., 2001; C. Taylor, written commun., 2001) and much higher than in the VMS deposits on Prince of Wales Island. Data for the Windy Craggy deposit (Peter and Scott, 1999), in contrast, overlap the most radiogenic analyses for the VMS deposits on Prince of Wales Island. Age-equivalent comparisons of $\mathrm{Pb}$-isotopic compositions indicate that the Greens Creek and Windy Craggy deposits probably did not share a common lead source with the VMS deposits on Prince of Wales Island. Similarly, the massive sulfide occurrences (for example, Duncan Canal, Pyrola, and Woewodski; Newberry and Brew, 1997) in the Admiralty Island terrane north of Prince of Wales Island that are part of the Triassic mineralized belt are also more radiogenic than the VMS deposits on Prince of Wales Island. The large differences in ${ }^{207} \mathrm{~Pb} /{ }^{204} \mathrm{~Pb}$ ratio at a given ${ }^{206} \mathrm{~Pb} /{ }^{204} \mathrm{~Pb}$ ratio suggest that the lead in VMS deposits in different parts of the Alexander terrane evolved from sources with heterogeneous $\mu$ values. $\mathrm{Pb}$-isotopic signatures of the Jurassic Eskay Creek deposit (Childe, 1996) in the Stikinia terrane are also radiogenic in comparison with the VMS deposits on Prince of Wales Island, consistent with a model in which the Alexander and Stikinia terranes did not share a common lead source. The contrast in $\mathrm{Pb}$-isotopic compositions between the Greens Creek deposit and the VMS deposits on Prince of Wales Island is consistent with the suggestion that translational faults juxtaposed these areas before the Triassic (Karl and others, 1999b).

The Devonian polymetallic quartz-sulfide veins on Prince of Wales Island (for example, at the Dew Drop, Lady of the Lake, Lucky Boy, Moonshine, and Port Bazan deposits) are also significantly less radiogenic than the Greens Creek deposit and massive sulfide occurrences on Admiralty Island, veins in the Taku terrane (Gacetta and Church, 1989), and Devonian or younger massive sulfide deposits in the and Taku and Yukon-Tanana terranes (Godwin and others, 1988; Gacetta and Church, 1989; Newberry and Brew, 1997). The contrast, particularly in ${ }^{207} \mathrm{~Pb} /{ }^{204} \mathrm{~Pb}$ ratio, suggests that the veins in the Alexander and Taku terranes did not share a common lead source. Our data also indicate that on Gravina Island, the Cretaceous massive sulfide deposits (Godwin and others, 1988), 
Mesozoic(?) veins at the Goldstream deposit, and Triassic(?) veins at the Seal Cove deposit are isotopically similar to the polymetallic quartz-sulfide veins on Prince of Wales Island. On this basis, a common lead source likely existed for these deposits and veins that links Gravina Island to the Alexander terrane. The Seal Cove deposit is unique because it is the only example of Triassic(?) mineralization with associated $\mathrm{Pb}-$ isotopic compositions resembling those of the veins on Prince of Wales Island. Although a conclusive explanation for this exceptional similarity is impossible with the data on hand, the Seal Cove deposit may not be Triassic, or if it is, contemporaneous lead sources contributing to the mineralization in southeastern Alaska must have varied regionally.

\section{Conclusions}

The VMS deposits on Prince of Wales Island and vicinity are associated with Late Proterozoic through Cambrian Wales Group volcanosedimentary rocks and with Ordovician through Early Silurian felsic volcanic rocks of the Moira Sound unit. $\mathrm{Pb}$-isotopic signatures were determined by using sulfide minerals (galena, pyrite, chalcopyrite, pyrrhotite, and sphalerite). $\mathrm{Pb}$ isotopic compositions distinguish the massive sulfide deposits in the Wales Group from those in the Moira Sound unit. The $\mathrm{Pb}$-isotopic ratios for all these deposits are lower than those on the average crustal Pb-evolution curve of Stacey and Kramers (1975). A mantle component in the lead source controlled the $\mathrm{Pb}$ evolution of all the VMS deposits on Prince of Wales Island; no evidence exists that the lead evolved in the upper or lower continental crust. $\mathrm{Pb}$-isotopic data for the massive sulfide deposits in the Moira Sound unit slightly overlap the trend for those in the Wales Group but are more radiogenic. The low ${ }^{207} \mathrm{~Pb} /{ }^{204} \mathrm{~Pb}$ ratios all these deposits indicate that the most likely lead (and metal) sources were associated with oceanic volcanic rocks in an intraoceanic-arc environment. A small lead contribution from reworked arc material or recycled older, hydrothermally altered oceanic crust (including pelagic sediment) is also possible. The massive sulfide deposits in the Moira sound unit may include remobilized lead from rocks of the Wales Group. Regional comparison of $\mathrm{Pb}$-isotopic signatures indicates that the Greens Creek and Windy Craggy deposits did not share a common lead source with the VMS deposits on Prince of Wales Island. Other massive sulfide occurrences on Admiralty Island are also more radiogenic than those on Prince of Wales Island. The large differences in ${ }^{207} \mathrm{~Pb} /{ }^{204} \mathrm{~Pb}$ ratio imply that the lead in massive sulfide deposits in the Alexander terrane evolved from sources with diverse $\mu$ values.

\section{References Cited}

Bennett, V.C., Esat, T.M., and Norman, M.D., 1996, Twomantle plume components in Hawaiian picrites inferred from correlated Os-Pb isotopes: Nature, v. 381, no. 6579, p. 221-224.
Berg, H.C., Jones, D.L., and Richter, D.H., 1972, GravinaNutzotin belt-tectonic significance of an upper Mesozoic sedimentary and volcanic sequence in southern and southeastern Alaska: U.S. Geological Survey Professional Paper 800-D, p. D1-D24.

Blodgett, R.B., Rohr, D.M., and Boucot, A.J., 2002, Paleozoic links among some Alaskan accreted terranes and Siberia based on megafossils, in Miller, E.L., Grantz, A., and Klemperer, S.L., eds., Tectonic evolution of the Bering ShelfChukchi Sea-Arctic margin and adjacent landmasses: Geological Society of America Special Paper 360, p. 273-291.

Brevart, O., Dupre, B., and Allegre, C., 1981, Metallogenesis at spreading centers; lead isotope systematics for sulfides, manganese-rich crusts, basalts, and sediments from the Cyamex and Alvin areas (East Pacific Rise): Economic Geology, v. 76, no. 5, p. 1205-1210.

Childe, F., 1996, U-Pb geochronology and $\mathrm{Nd}$ and $\mathrm{Pb}$ isotope characteristics of the Au-Ag-rich Eskay Creek volcanogenic massive sulfide deposit, British Columbia: Economic Geology, v. 91, no. 7, p. 1209-1224.

Churkin, M., Jr., and Eberlein, G.D., 1977, Ancient borderland terranes of the North American Cordillera; correlations and microplate tectonics: Geological Society of America Bulletin, v. 88, no. 6, p. 769-786.

Cousens, B.L., Blenkinsop, J., and Franklin, J.M., 2002, Lead isotope systematics of sulfide minerals in the Middle Valley hydrothermal system, northern Juan de Fuca Ridge: Geochemistry, Geophysics, Geosystems, v. 3(5), 10.1029/2001GC000257, 2002, 16 p.

Cumming, G.L., and Krstic, D., 1987, Detailed lead isotope study of Buchans and related ores, in Kirkham, R.V., ed., Buchans geology, Newfoundland: Geological Survey of Canada Paper 86-24, p. 227-233.

Doe, B.R., Delevaux, M.H., and Alpers, J.P., 1985, The plumbotectonics of the West Shasta mining district, eastern Klamath Mountains, California: Economic Geology, v. 80, no. 8, p. 2136-2148.

Doe, B.R., and Zartman, R.E., 1979, Plumbotectonics; I, The Phanerozoic, in Barnes, H.L., ed., Geochemistry of hydrothermal ore deposits ( $2 \mathrm{~d}$ ed.): New York, John Wiley and Sons, p. 22-70.

Dupre, B., and Allegre, C.J., 1983, Pb-Sr variation in Indian Ocean basalts and mixing phenomena: Nature, v. 303, no. 5913, p. 142-146.

Eberlein, G.D., Churkin, M., Jr., Carter, C., Berg, H.C., and Ovenshine, A.T., 1983, Geology of the Craig quadrangle, Alaska: U.S. Geological Survey Open-File Report 83-91, 53 p.

Elliott, T., Plank, T., Zindler, A., White, W., and Bourdon, B., 1997, Element transport from slab to volcanic front in the Mariana arc: Journal of Geophysical Research, v. 102, no. B7, p. 14991-15019.

Farmer, G.L., and DePaolo, D.J, 1997, Sources of hydro- 
thermal components; heavy isotopes, in Barnes, H.L., ed., Geochemistry of hydrothermal ore deposits ( $3 \mathrm{~d}$ ed.): New York, John Wiley and Sons, p. 31-61.

Fouquet, Y., and Marcoux, E., 1995, Lead isotope systematics in Pacific hydrothermal sulfide deposits: Journal of Geophysical Research, v. 100, no. B4, p. 6025-6040.

Gacetta, J.D., and Church, S.E., 1989, Pb isotope database for sulfide occurrences from Alaska, December 1989: U.S. Geological Survey Open-File Report 89-688, 60 p.

Gehrels, G.E., 1990, Late Proterozoic-Cambrian metamorphic basement of the Alexander terrane on Long and Dall Islands, southeast Alaska: Geological Society of America Bulletin, v. 102, no. 6, p. 760-767.

Gehrels, G.E., 1992, Geologic map of southern Prince of Wales Island, southeastern Alaska: U.S. Geological Survey Miscellaneous Investigations Series Map I-2169, 23 p., scale 1:63,360.

Gehrels, G.E., and Berg, H.C., 1992, Geologic map of southeastern Alaska: U.S. Geological Survey Miscellaneous Investigations Series Map I-1867, 24 p., scale 1:600,000.

Gehrels, G.E., Butler, R.F., and Bazard, D.R., 1996, Detrital zircon geochronology of the Alexander terrane, southeastern Alaska: Geological Society of America Bulletin, v. 108, no. 6, p. 722-734.

Gehrels, G.E., and Saleeby, J.B., 1987, Geology of southern Prince of Wales Island, southeastern Alaska: Geological Society of America Bulletin, v. 98, no. 2, p. 123-137.

Gehrels, G.E., Saleeby, J.B., and Berg, H.C., 1983a, Geology of Annette, Gravina and Duke Islands, southeastern Alaska: Canadian Journal of Earth Sciences, v. 24, no. 5, p. 866-881.

Gehrels, G.E., Saleeby, J.B., and Berg, H.C., 1983b, Preliminary description of the Klakas orogeny in the southern Alexander terrane, southeastern Alaska, in Stephens, C.H., ed., Pre-Jurassic rocks in western North American suspect terranes: Los Angeles, Society of Economic Paleontologists and Mineralogists, Pacific Section, p. 131-141.

Godfrey, L.V., Mills, R., Elderfield, H., and Girvich, E., 1994, Lead behaviour at the TAG hydrothermal vent field, $26^{\circ} \mathrm{N}$, Mid-Atlantic Ridge: Marine Chemistry, v. 46, no. 3, p. 237-254.

Godwin, C.I., Gabites, J.E., and Andrew, A., 1988, Leadtable; galena lead isotope database for the Canadian Cordillera, with a guide to its use by explorationists: British Columbia Geological Survey Mineral Resources Division Paper 1988-4, 188 p.

Goldfarb, R.J., 1997, Metallogenic evolution of Alaska, in Goldfarb, R.J., and Miller, L.D., eds., Mineral deposits of Alaska: Economic Geology Monograph 9, p. 4-34.

Gribble, R.F., Stern, R.J., Newman, S., Bloomer, S.H., and O'Hearn, T., 1998, Chemical and isotopic composition of lavas from the northern Mariana Trough; implications for magmagenesis in back-arc basins: Journal of Petrology, v. 39 , no. 1 , p. 125-154.

Halbach, P., Hansman, W., Koppel, V., and Pracejus, B., 1997, Whole rock and sulfide lead-isotope data from the hydrothermal JADE field in the Okinawa back-arc trough: Mineralium Deposita, v. 32, no. 1, p. 70-78.

Hamelin, B., and Allegre, C.J., 1985, Large-scale regional units in the depleted upper mantle revealed by an isotope study of the Southwest Indian Ridge: Nature, v. 315, no. 6016, p. 196-199.

Herreid, G., Bundtzen, T.K., and Turner, D.L., 1978, Geology and geochemistry of the Craig A-2 quadrangle, Prince of Wales Island, southeastern Alaska: Alaska Division of Geological and Geophysical Surveys Geologic Report 48, 49 p.

Hochstaedter, A.G., Gill, J.B., and Morris, J.D., 1990, Volcanism in the Sumisu Rift, II. Subduction and non-subductionrelated components: Earth and Planetary Science Letters, v. 100, no. 1, p. 195-209.

Hofmann, A.W., 1997, Mantle geochemistry; the message from oceanic volcanism: Nature, v. 385,no. 6613, p. 219-229.

Ito, E., White, W.M., and Gopel, C., 1987, The O, Sr, Nd and $\mathrm{Pb}$ isotope geochemistry of MORB: Chemical Geology, v. 62, no. 3-4, p. 157-176.

Jones, D.L., Irwin, W.P., and Ovenshine, A.T., 1972, Southeastern Alaska- a displaced continental fragment?: U.S. Geological Survey Professional Paper 800-B, p. B211B217.

Karl, S.M., Haeussler, P.J., Mortensen, J.K., Layer, P.W., Savage, N., Wardlaw, B., Harris, A., Murchey, B., and Blome, C., 1999a, New stratigraphic and isotopic constraints on the depositional and deformational history of the Alexander terrane, southeastern Alaska: Geological Society of America Abstracts with Programs, v. 31, no. 6, p. A-68.

Karl, S.M., Haeussler, P.J., Mortensen, J.P., Layer, P., Soja, C.M., and Himmelberg, G.R., 1999b, Incremental Paleozoic amalgamation of the composite Alexander/Wrangellia/Taku terrane, southeastern Alaska [abs.], in Evenchick, C.A., Woodsworth, G.J., and Jongens, R., eds., Terrane Paths 99: Circum-Pacific Terrane Conference, Okanaga Valley, British Columbia, Canada, 1999, Abstracts and Program, p. 44.

Karl, S.M., Slack, J.F., Shanks, W.C., III, Ayuso, R.A., Wooden, J.L., Layer, P.W., Haeussler, P.J., and Zumsteg, C.L., 2003, Paleozoic and Proterozoic VMS deposits on Prince of Wales Island and adjacent islands, Southeast Alaska: Alaska Miners Association 2003 Annual Convention, Anchorage, 2003, Abstracts, p. 14-15.

Karl, S.M., Layer, P., Ayuso, R.A., Haeussler, P.J., Zumsteg, C.L., Shew, N.B., and Bittenbender, P.E., 2005, Gold- and copper-bearing quartz veins associated with regional Devonian extensional deformation in rocks on Prince of Wales Island, southeastern Alaska, in Fowler, S. J., ed., Alaska 
Geological Society 2005 Geology Symposium: Anchorage, Alaska Geological Society, p. 18-19.

Kucinski, R.M., 1987, Geology and mineralization of the Ruby Tuesday claim block, Prince of Wales Island, southeastern Alaska: Fairbanks, University of Alaska, M.S. thesis, $105 \mathrm{p}$.

Lassiter, J.C., and Hauri, E.H., 1998, Osmium-isotope variations in Hawaiian lavas; evidence for recycled oceanic lithosphere in the Hawaiian plume: Earth and Planetary Science Letters, v. 164, no. 3-4, p. 483-496.

Ludwig, K.R., 1991, ISOPLOT-a plotting and regression program for radiogenic-isotope data: U.S. Geological Survey Open-File Report 91-445, 41 p.

Maas, K.M., Bittenbender, P.E., and Still, J.C., 1995, Mineralogical investigations in the Ketchikan mining district, southeastern Alaska: U.S. Bureau of Mines Open File Report 1-95, 606 p.

Mahoney, J., Le Roex, A.P., Peng, Z., Fisher, R.L., and Natland, J.H., 1992, Southwestern limits of Indian Ocean ridge mantle and the origin of low ${ }^{206} \mathrm{~Pb} /{ }^{204} \mathrm{~Pb}$ mid-ocean ridge basalt: isotope systematics of the Central Southwest Indian Ridge $\left(17^{\circ}-50^{\circ} \mathrm{E}\right)$ : Journal of Geophysical Research, v. 97, no. B13, p. 19771-19790.

Meijer, A., 1976, $\mathrm{Pb}$ and $\mathrm{Sr}$ isotopic data bearing on the origin of volcanic rocks from the Mariana island-arc system: Geological Society of America Bulletin, v. 87, no. 9, p. 1358-1369.

Monger, J.W.H., and Berg, H.C., 1987, Lithotectonic terrane map of western Canada and southeastern Alaska: U.S. Geological Survey Miscellaneous Field Studies Map MF-1874-B, 12 p., scale 1:2,500,000.

Monger, J.W.H., Price, R.A., and Templeman-Kluitt, D.J., 1982, Tectonic accretion and the origin of the two major metamorphic and plutonic welts in the Canadian Cordillera: Geology, v. 10, no. 2, p. 70-75.

Newberry, R.J., and Brew, D.A., 1997, Chemical and isotopic data for rocks and ores from the Upper Triassic Greens Creek and Woewodski Island volcanogenic massive sulfide deposits, southeastern Alaska: U.S. Geological Survey Professional Paper 1614, p. 35-55.

Newberry, R.J., Crafford, T.C., Newkirk, S.R., Young, L.E., Nelson, S.W., and Duke, N.A., 1997, Volcanogenic massive sulfide deposits in Alaska, in Goldfarb, R.J., Miller, L.D., eds., Mineral deposits of Alaska: Economic Geology Monograph 9, p. 120-150.

Norman, M.D., and Garcia, M.O., 1999, Primitive magmas and source characteristics of the Hawaiian plume; petrology and geochemistry of shield picrites: Earth and Planetary Science Letters, v. 168, no. 1-2, p. 27-44.

Peter, J.M., and Scott, S.D., 1999, Windy Craggy, northwestern British Columbia; the world's largest Besshi-type deposit, in Barrie, C.T., and Hannington, M.D., eds.,
Volcanic-associated massive sulfide deposits; processes and examples in modern and ancient settings: Reviews in Economic Geology, v. 8, p. 261-296.

Plank, T., and Langmuir, C.H., 1998, The chemical composition of subducting sediment and its consequences for the crust and mantle: Chemical Geology, v. 145, no. 3-4, p. 325-394.

Pollock, J.C., and Wilton, D.H.C., 2001, Metallogenic studies of the Tally Pond belt, Victoria Lake Group; trace element geochemistry and lead-isotope data from the Exploits subzone, in Pereira, C.P.G., Walsh, D.G., and Kean, B.F., eds., Newfoundland: Current Research (2001) Newfoundland and Labrador Geological Survey Report 2001-1, p. 247-266.

Richards, J.P., and Noble, S.R., 1998, Application of radiogenic isotope systems to the timing and origin of hydrothermal processes, in Richards, J.P., and Larson, P.B., eds., Techniques in hydrothermal ore deposits geology: Reviews in Economic Geology, v. 10, p. 195-233.

Roden, M.F., Trull, T., Hart, S.R., and Frey, F.A., 1994, New $\mathrm{He}, \mathrm{Nd}, \mathrm{Pb}$, and $\mathrm{Sr}$ isotopic constraints on the constitution of the Hawaiian plume; results from Koolau Volcano, Oahu, Hawaii, USA: Geochimica et Cosmochimica Acta, v. 58, no. 5 , p. 1431-1440.

Samson, S.D., McClelland, W.C., Patchett, J.P., Gehrels, G.E., and Anderson, R.G., 1989, Evidence from neodymium isotopes for mantle contributions to Phanerozoic crustal genesis in the Canadian Cordillera: Nature, v. 337, no. 6209 , p. 705-709.

Samson, S.D., Patchett, J.P., McClelland, W.C., and Gehrels, G.E., 1991, Nd isotopic characterization of metamorphic rocks in the Coast Mountains, Alaskan and Canadian Cordillera; ancient crust bounded by juvenile terranes: Tectonics, v. 10, no. 4, p. 770-780.

Sato, K., and Sasaki, A., 1980, Lead isotopic feature of the Besshi-type deposits and its bearing on the ore lead evolution: Geochemical Journal, v. 14, no. 6, p. 303-315.

Soja, C.M., and Antoshkina, A.I., 1997, Coeval development of Silurian stromatolite reefs in Alaska and the Ural Mountains; implications for paleogeography of the Alexander Terrane: Geology, v. 25, no. 6, p. 539-542.

Stacey, J.S., and Kramers, J.D., 1975, Approximation of terrestrial lead isotope evolution by a two-stage model: Earth and Planetary Sciences Letters, v. 26, no. 2, p. 207-221.

Stern, R.J., and Ito, E., 1983, Trace element and isotopic constraints on the source of magmas in the active volcano and Mariana island arcs, western Pacific: Journal of Volcanology and Geothermal Research, v. 18, no. 1-4, p. 461-482.

Stille, P., Unruh, D.M., and Tatsumoto, M., 1983, Pb, Sr, Nd and $\mathrm{Hf}$ isotopic evidence of multiple sources for Oahu, Hawaii basalts: Nature, v. 304, no. 5921, p. 25-29.

Stuart, F.M., Ellam, R.M., and Duckworth, R.C., 1999, Metal sources in the Middle Valley massive sulphide deposit, 
northern Juan de Fuca Ridge; $\mathrm{Pb}$ isotope constraints: Chemical Geology, v. 153, no. 1-4, p. 213-225.

Swinden, H.S., 1996, The application of volcanic geochemistry to the metallogeny of volcanic-hosted sulphide deposits in central Newfoundland, in Wyman, D.S., ed., Trace element geochemistry of volcanic rocks; applications for massive sulphide exploration: Geological Association of Canada Short Course Notes, v. 12, p. 329-358.

Swinden, H.S., and Thorpe, R.I., 1984, Variations in style of volcanism and massive sulfide deposition in Early to Middle Ordovician island-arc sequences of the Newfoundland Central Mobile Belt: Economic Geology, v. 79, no. 7, p. 1596-1619.

Taylor, C.D., Newkirk, S.R., Hall, T.E., Lear, K.G., Premo, W.R., Leventhal, J.S., Meier, A.L., Johnson, C.A., and Harris, A.G., 1999, The Greens Creek deposit, southeastern Alaska; a VMS-SEDEX hybrid, in Stanley, C.J., ed., Mineral deposits; processes to processing: Rotterdam, Balkema, v. 1 , p. $597-600$.
Taylor, R.N., and Nesbitt, R.W., 1998, Isotopic characteristics of subduction fluids in an intra-oceanic setting, Izu-Bonin arc, Japan: Earth and Planetary Science Letters, v. 164, no. 1-2, p. 79-98.

Verati, C., Lancelot, J., Fouquet, Y., and Bendel, V., 1994, Compositions isotopiques en plomb des minéralisations océaniques hydrothermales et hétérogenéités de la dorsale d'arrière-arc du Basin-Nord-Fidjien (SW Pacifique): Comptes Rendus de l'Académie des Sciences, v. 319, ser. 2, no. 8, p. 921-928.

White, W.M., Hofmann, A.W., and Puchelt, H., 1987, Isotope geochemistry of Pacific mid-ocean ridge basalt: Journal of Geophysical Research, v. 92, no. B6, p. 4881-4893.

Zumsteg, C.L., Karl, S.M., Haeussler, P.J., and Himmelberg, G.R., 2004, Recognition of three metamorphic events within the Wales Group on Prince of Wales and Dall Islands, southeastern Alaska [abs.]: Geological Society of America Abstracts with Programs, v. 36, no. 5, p. 135. 